\title{
ANUARIO IBEROAMERICANO DE JUSTICIA CONSTITUCIONAL
}

\section{7 \\ 2013}

Anuario Iberoamericano de Justicia Constitucional ISSN: 1138-4824, Madrid 2013, núm. 17 


\section{CONSEJO DE REDACCIÓN \\ DIRECTOR: Francisco Fernández Segado \\ SECRETARIO: Alberto Oehling de los Reyes}

\section{VOCALES}

Raúl Canosa Usera. Universidad Complutense de Madrid Domingo García Belaunde. Pontificia Universidad Católica del Perú Ricardo Haro. Universidad Nacional de Córdoba, Argentina Jorge Miranda. Universidad de Lisboa

\section{CONSEJO ASESOR}

\section{ARGENTINA}

Walter F. Carnota. Univ. Buenos Aires Alberto R. Dalla Via. Univ. Buenos Aires Antonio María Hernández. Univ. Nal. Córdoba Juan Carlos Hitters. Univ. de La Plata Dardo Pérez Guilhou. Univ. Nal. del Cuyo Daniel Alberto Sabsay. Univ. Buenos Aires Néstor Pedro Sagüés. Univ. Buenos Aires Jorge Reinaldo Vanossi. Univ. Buenos Aires Alberto Zarza Mensaque. Univ. Nal. Córdoba

\section{BOLIVIA}

Jorge Asbun Rojas. UPSA

Pablo Dermizaky Peredo. Univ. San Simón Benjamín Miguel Harb. Univ. San Andrés Luis Ossio Sanjinés. Univ. Andina

José Antonio Rivera Santiváñez. Univ. San Simón

\section{BRASIL}

José Afonso da Silva. Univ. São Paulo Celso Antônio Bandeira de Mello. Univ. Católica São Paulo

José Carlos Barbosa Moreira. Univ. Rio de Janeiro

Luís Roberto Barroso. Univ. Rio de Janeiro

Paulo Bonavides. Univ. F. Ceará

Dalmo A. Dallari. Univ São Paulo

Ivo Dantas. Univ. F. Pernambuco

Gilmar Ferreira Mendes. Supremo Tribunal Fed. Manoel Gonçalves Ferreira Filho. Univ. São Paulo Eros Roberto Grau. Supremo Tribunal Fed. Regina María Macedo Nery Ferrari. Univ. Curitiba José M. ${ }^{a}$ Othon Sidou. Academia Brasileira Letras Jurídicas

Lenio Luiz Streck, UNISINOS, Porto Alegre.

\section{COLOMBIA}

Manuel José Cepeda Espinosa. Univ. Ios Andes Eduardo Cifuentes Muñoz. Univ. Ios Andes Augusto Hernández Becerra. Univ. Externado Fabio Morón Díaz. Corte Constitucional Julio César Ortiz. Univ. Externado Carlos Restrepo Piedrahita. Univ. Externado Álvaro Tafur Galvis. Corte Constitucional Jaime Vidal Perdomo. Corte Constitucional

\section{COSTA RICA}

Rubén Hernández Valle. Univ. de Costa Rica Luis Paulino Mora Mora. Tribunal Supremo

\section{CUBA}

Diego F. Cañizares Abeledo. Univ. La Habana Eduardo Lara Hernández. Unión Nac. Juristas

\section{CHILE}

José Luis Cea Egaña. Univ. Católica Humberto Nogueira Alcalá. Univ. Talca Lautaro Ríos Alvarez. Univ. Valparaíso Fernando Saenger Gianoni. Univ. Católica de Concepción

Alejandro Silva Bascuñán. Univ. Central

\section{ECUADOR}

Rodrigo Borja. Univ. de Quito

Oswaldo Cevallos Bueno. Tribunal Constit.

Hernán Salgado Pesantes. Univ. Católica

\section{EL SALVADOR}

Salvador Enrique Anaya. Univ. El Salvador Mario Antonio Solano Ramírez. Trib. Supremo

\section{ESPAÑA}

Eliseo Aja. Univ. Barcelona

Óscar Alzaga. UNED

Miguel Ángel Aparicio. Univ. Barcelona

Manuel Aragón Reyes. Trib. Constitucional

Roberto L. Blanco Valdés. Univ. Santiago

José Luis Cascajo. Univ. Salamanca

Javier Corcuera Atienza. Univ. País Vasco

Pedro Cruz Villalón. Univ. Autónoma Madrid

Eduardo Espín Templado. Tribunal Supremo

Teresa Freixes Sanjuán. Univ. Autónoma de Barcelona

Manuel B. García Álvarez. Univ. León

Mariano García Canales. Univ. Murcia

Javier García Fernández. Univ. Alicante

Javier García Roca. Univ. Valladolid

Ángel Garrorena Morales. Univ. Murcia

Pedro J. González-Trevijano. Univ. Rey Juan Carlos

Javier Jiménez Campo. Tribunal Constituciona Manuel Jiménez de Parga. Univ. Complutense Juan Fernando López Aguilar. Univ. Las Palmas Luis López Guerra. Univ. Carlos III

Pablo Lucas Murillo de la Cueva. Tribunal Supremo

Raúl Morodo Leoncio. Univ. Complutense

Joan Oliver Araújo. Univ. Islas Baleares

Alberto Pérez Calvo. Univ. Pública Navarra

Pablo Pérez Tremps. Tribunal Constitucional

Antonio Porras Nadales. Univ. Sevilla

Francisco Rubio Llorente. Consejo Estado

Pedro de Vega. Univ. Complutense

Jaume Vernet i Llobet. Univ. Tarragona

\section{GUATEMALA}

Jorge Mario García Laguardia. UNAM-Univ. de San Carlos

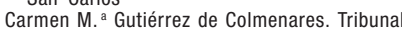
Constitucional

\section{HONDURAS}

José Rolando Arriaga M. Tribunal Supremo

\section{MÉXICO}

José Barragán Barragán. UNAM

José Ramón Cossío D. Suprema Corte de Just.

Eduardo Ferrer Mac-Gregor. UNAM.

Héctor Fix-Zamudio. UNAM

Sergio García Ramírez. Corte Interamericana

Mario Melgar Adalid. UNAM
J. Jesús Orozco Henríquez. Tribunal Electoral Federal

José Ovalle Favela. UNAM

José Luis Soberanes Fernández. Comisión Nacional de Derechos Humanos

Diego Valadés. UNAM

Salvador Valencia Carmona. UNAM

Arturo Zaldívar Lelo de Larrea. UNAM

\section{NICARAGUA}

Iván Escobar Fornos. Tribunal Supremo

\section{PANAMÁ}

Arturo Hoyos. Tribunal Supremo

Francisco Rodríguez Robles. Univ. de Panamá

\section{PARAGUAY}

Luis Lezcano Claude. Tribunal Supremo Jorge Seall-Sasiaín. Univ. de la República

\section{PERÚ}

Enrique Bernales Ballesteros. Univ. Católica de Perú

Alberto Borea Odría. Univ. del Perú

Francisco J. Eguiguren Praeli. Univ. Católica

César Landa Arroyo. Univ. Católica

Marcial Rubio Correa. Univ. Católica del Perú

\section{PORTUGAL}

José J. Gomes Canotilho. Univ. Coimbra

Vital M. Moreira. Univ. de Coimbra

Afonso d'Oliveira Martins. Univ. Os Lusiadas

María Fernanda Palma. Tribunal Constitucional

Marcelo Rebelo de Sousa. Univ. de Lisboa

\section{URUGUAY}

Rubén Correa Freitas. Univ. de la Empresa Eduardo Esteva Gallicchio. Univ. Católica

Daniel Hugo Martins. Univ. de Punta del Este

Martín Risso Ferrand. Univ. Católica de Uruguay

\section{VENEZUELA}

Asdrúbal Aguiar Aranguren. Univ. Cat. Andrés Bello

José Guillermo Andueza. Univ. Central de Venezuela

Carlos M. Ayala Corao. Univ. Católica Andrés Bello

Allan R. Brewer-Carías. Univ. Central de Venezuela

Josefina Calcaño de Temeltas. Academia de Legislación y Jurisprudencia

Ricardo Combellas. Univ. Central de Venezuela 


\title{
COMPARATIVE LAW: PERSPECTIVES OF LEGISLATION
}

ULRICH KARPEN*

\begin{abstract}
SUMARIO
I. InTRODUCTION.-II. LEGISLATION AND LEgistics AS A SUBJECT OF COMPARATIVE LAW. 1. The Law as a Subject of Legistics (Analysis of Law). 2. Good Governance, Better Regulation, Better Legislation. 3. Methods of Comparative Law. 4. Unification of Law.-III. Process of LEgislation. 1. Competences, Organisation and Procedure of Legislation. 2. Legislation in Multi-level Systems. 3. Organisation of Legislation and Separation of Powers. 4. Legislation in the Regulatory Cycle.-IV. GOALS, INSTRUMENTS AND EVALUATION OF LEGISLATION. 1. Legislation in the Regulatory Cycle. 2. Political Aims, Goals and Instruments of Legislation. 3. Evaluation of Legislation. 4. Regulatory Impact Assessment.-V. TeChNiQues of Legislation. 1. Law Drafting. 2. Structure, Language, References. 3. Special Categories of Laws (Amendments and so on.). 4. Guidelines and Manuals for Law-Making.-VI. CONCLUSION: SOME TRENDS OF LEGISLATION AND LEGISTICS.
\end{abstract}

\section{RESUMEN}

El Estado moderno se enfrenta a una inflación de leyes y de otras regulaciones. Muchas de ellas se hacen imperfectas e incluso malamente. La "legística" o "legisprudencia" como investigación, enseñando y aprendiendo de la producción de la ley intenta reducir la cantidad y mejorar la calidad de las normas. Trata del análisis de las normas, de la organización y del procedimiento de elaboración de normas, contenido de la ley, técnicas legislativas y de comprobar adecuadamente la eficaz aplicación de las regulaciones. La "ciencia legislativa" desea contribuir a la mejor regulación como elemento esencial de un "buen gobierno". Este artículo presenta un panorama de problemas y de posibles soluciones de legislación, principal, aunque no exclusivamente, de conformidad con los aspectos jurídicos de las constituciones de los Estados de tradición occidental, impresas por los derechos humanos, la democracia y el Estado de Derecho.

* Ulrich Karpen is Professor of Law at the University of Hamburg, Germany.

Anuario Iberoamericano de Justicia Constitucional ISSN 1138-4824, núm. 17, Madrid (2013), págs. 141-185 
Palabras clave: Derecho comparado; métodos de legislación; competencias; sistema a diferentes niveles; separación de poderes; círculo regulador; programa político; objetivos jurídicos; instrumentos jurídicos; evaluación; impacto regulador de la evaluación; Estados federales; estructura jurídica; lenguaje jurídico; enmiendas; remisiones; Derecho presupuestario; líneas directrices para la legislación; manuales para la legislación.

\begin{abstract}
The modern State faces an inflation of laws and other regulations. Many of them are imperfectly, even badly done. 'Legistics' or 'legisprudence' as research, teaching and learning of law-production tries to reduce quantity and improve quality of norms. It deals with analysis of norms, organisation and procedure of norm setting, content of law, legislative techniques and properly monitoring effective implementation of regulations. 'Legislative Science' wants to contribute to 'better regulation' as essential element of 'good governance'. This paper presents a survey of problems and possible solutions of legislation, mainly - although not exclusively - under legal aspects of the Constitutional State of the Western Tradition, as imprinted by Human Rights, Democracy and Rule of Law.

Key words: Comparative law; methods of legislation; unification of law; competences; multi-level system; separation of powers; regulatory circle; political programme; aims of law; instruments of law; evaluation; regulatory impact assessment; federal states; structure of law; legal language; amendments; cross referencing; budget-law; guidelines for legislation; manuals for legislation.
\end{abstract}

\title{
I. INTRODUCTION
}

Legislation and legistics till now have been looked at as national matters. However, since the beginning of European Integration and worldwide growing together of economy and legal systems as part of 'globalisation' Comparative Lawis standard of legal research. «Comparative Law in the light of European Legal Space is today's business.» ${ }^{1}$ This, of course, is true for Non-European countries. For the European Union comparative law is mandatory, for Article 6(3) of the Lisbon-Treaty (Treaty on European Union or 'TEU') refers to the 'constitutional traditions common to the Member States', which indeed are sources of law which could be concretised only by comparative research.

For this presentation a selection of legal orders is necessary. For the civil law family the 'Germanic' area is represented by German, Austrian and Swiss Law, also by the related Spanish body of law; the 'Roman' law

${ }^{1}$ A. von Bogdandy et al. (eds.), Handbuch Ius Publicum Europaeum (vol. 1, C. F. Müller 2007) v. 
circle by France and Italy. As far as common law is concerned, the focus is on the United Kingdom and the U.S.A., with some side-glance to Canada. For legislation in Nordic Countries Sweden is of particular interest. The law of the Netherlands is a mixture of Common European Law-elements. The Netherlands need to particularly be taken into account due to their activities in supporting legistics. The Balkan-countries Croatia, Serbia, Macedonia, Kosovo, Bosnia and Hercegovina and Albania make primarily efforts to adapt their legal orders to European Union-law and member states standards as a prerequisite to accession. They have in particular to implement the acquiscommunautaire into national law. Many experts in the field of legislation theory and practice (legistics) are involved in this process of transformation, which means in effect that legistics undergo an 'in vivo' test. ${ }^{2}$ All reference countries are of the 'Western Constitutionalism-type'.

Forty years ago the Swiss Peter Noll ${ }^{3}$ awakened the 'Sleeping Beauty Legistics' ${ }^{4}$ Since then, next to the traditional topics language, methodology, techniques of law and so on, new strongpoints have been developed, which today dominate the discussion: law inflation, deregulation, debureaucratisation, participation of experts and stakeholders in the drafting process, juridification of goals and means of legislation, regulatory impact assessment.

This paper deals with these issues in four parts: (i) Contribution of Comparative Law to 'better regulation'; (ii) Process of legislation: actors, organs, steps of procedure; (iii) Policy, goals, instruments of the law; (iv) Techniques of legislation: structure of the draft, language, references and so on. Finally, legistics as a science of legislation and the law (i) deals with the problems 'who (ii) - why (iii) - how (iv)'. ${ }^{5}$ Comparative law widens our perspective. One of the well-known aphorisms of the psychiatrist Scott Peck suggests, 'that we should share our similarities and celebrate our differences' ${ }^{6}$ If we understand why and how others legislate differently than how we do, then we are encouraged to compare and learn and improve our methods or stay with our legislative style.

${ }^{2}$ U. KARPEN, Draft Law on General Administrative Proceduresof the Republic of Croatia, Introduction and Arguments of the Legal Text-A Drafting Report-, Berichte, (2012) 60 JöRNF 431; U. KARPEN, 'Der DistriktBrèko (in B/H): Verfassung und Recht' (2011) 59 JöRNF 665; T. Temelkoska-Milenkovic and U. KARPEN, Manual on Secondary Lawmaking (OECD 2010).

${ }^{3}$ P. NoLL, Gesetzgebungslehre (Reinbek 1973).

${ }^{4}$ As to the tradition of this science, see B. MERTENS, Gesetzgebungskunst im Zeitalter der Kodifikationen (Mohr Siebeck 2004); S. EMMENEGGER, Gesetzgebungskunst (Mohr Siebeck 2005).

${ }^{5}$ L. Tribe, American Constitutional Law (2nd edn., Foundation Press 1988) 1682.

${ }^{6}$ W. Voermans, 'Styles of Legislation and Their Effects' in 32(1) Statute Law Review 38. 


\section{LEGISLATION AND LEGISTICS AS A SUBJECT OF COMPARATIVE LAW}

\section{The Law as a Subject of Legistics (Analysis of Law)}

This holds true for (i) regulatory theory, (ii) better regulation, (iii) comparative law-methods and (iv) approximation of law: «Legislation [is] the general binding establishment of legal norms, as enacted by an authority.» ${ }^{7}$ The law is the primary and central instrument of government in a democratic social rule-of-law state. ${ }^{8}$ The law is the frame of the order of the state, protects individual freedoms and serves as the single most important instrument to distribute and allot social expenditures. The law mirrors as well the values which, basically, are consented in the society and which are lighthouses and directives for governmental actions. ${ }^{9}$ Essential regulations regarding politics, governmental and administrative activities need to be enacted by statutory law. ${ }^{10}$ Laws are general, abstract norms, not decisions in a particular case. ${ }^{11}$

The term 'legislation' does not cover only formal laws, i.e. statutes, as enacted by parliament. Legistics as science of the law is interested as well in norms, which rank in the hierarchy of regulations under statutory law, like delegated legislation (secondary legislation); by-laws and administrative regulations. Demands of competence and procedure, goals and drafting techniques apply to them as well. In this sense, 'legistics' is science of 'law making', 'regulation'. This paper will, however, concentrate on primary and secondary legislation.

All constitutions regulate on the enactment of constitutional law and amendments as highest ranking and preceding pieces of legislation: They

${ }^{7}$ H. SCHNEIDER, Gesetzgebung (3rd edn., C.F. Müller 2002) 29.

${ }^{8}$ W. ISMAYR (ed.), Gesetzgebung in Westeuropa (VS Verlag für Sozialwissenschaften 2008) 12.

${ }^{9}$ G. BIAGginI, 'Grundlagen und Grundzüge Staatlichen Verfassungsrechts: Schweiz' in A. von Bogdandy et al. (eds.), Handbuch Ius Publicum Europaeum (vol 1, C.F. MÜLler 2007) no. 21; L. TRIBE, American Constitutional Law (3rd edn., Foundation 2000) 859.

${ }^{10}$ BVerfGE 49, 89 (126) (German Constitutional Court orGCC); A. WeBER, Europäische Verfassungsvergleichung (Verlag C.H. Beck 2010) 199. This is true particularly for Austria and Switzerland. According to the Swiss Constitution (art. 164 I), regulation of 'important basical' issues is reserved to parliament, see G. BIAGGINI, 'Grundlagen und Grundzüge Staatlichen Verfassungsrechts: Schweiz' in A. von Bogdandy et al. (eds.), Handbuch Ius Publicum Europaeum (vol. 1, C. F. MÜLlER 2007) no. 86; U. KARPEN, Gesetzgebungslehre: Neu Evaluiert / Legistics: Freshly Evaluated (2nd edn., 2008) 13.

${ }^{11}$ See art. 288(2) TFEU; L. TRIBE, American Constitutional Law (2nd edn., Foundation Press 1988) 630; G. KIRCHHOF, Die Allgemeinheit des Gesetzes (2009); A. JASIAK, Constitutional Constraints on Ad Hoc Legislation, A Comparative Study on the United States, Germany and the Netherlands (2010). For all Swedish norm categories (Grundlagar, Lagar, Förordningar, Föreskrifter) it is established that they must be of general binding force: H.H. VoGEL in A. VON BoGDANDY et al. (eds.), Handbuch Ius Publicum Europaeum (vol. 1, C. F. MÜLLER 2007) 113. 
need to be approved by parliament or/and referenda. ${ }^{12}$ Some countries (like the Netherlands, France, Spain, Italy, Croatia and Macedonia) in addition know organic laws (leyes orgánicas), which concretise constitutional provisions and are ranking in-between constitution and statutory law. ${ }^{13}$

Admissibility and use of regulations ranking lower than statutory law is different and in some countries not very transparent (secondary, subordinate, delegated legislation, governmental or administrative rule-making, rules, ordonnances, decrets, decret-loi and so on). Some legal systems - like the European Union (Article 290(1)(2) Treaty on the Functioning of the European Union or 'TFEU') - require, that the legislative act, which delegates (non-statutory) legislative power of general application to the executive, must explicitly define the 'objectives, content, scope and duration of the delegation'. "The essential elements of an area shall be reserved for the legislative act.» (ibid.) Obviously, there are no explicit prohibitions of delegated legislation. ${ }^{14}$ The terminology of subparliamentary provisions in the United Kingdom demonstrates a 'bewildering variety': statutory instruments, codes of practice, rules, and so on. ${ }^{15}$ The French Constitution recognises two types of delegated legislation: those, which on the basis of general authorisation (Article 37) - are adopted by government and conseild'État (decret-lois) and those which the government releases on the basis of a special parliamentary authorisation (loid'habilitation, Article 38) (ordonnances). These constitutional provisions weaken the role of parliament, which is dominated by President and Government anyway. ${ }^{16}$ For all countries it is fact that delegated legal acts by far outnumber statutory law. ${ }^{17}$ This is a problem in a parliamentary democracy: on the one hand it sheds light on the (often at short sight necessary) enlargentment of public tasks which could be managed only by the executive. On the other hand it contributes to the creeping loss of parliamentary power. ${ }^{18}$

${ }^{12}$ P. Cruz Villalón in A. von Bogdandy et al. (eds.), Handbuch Ius Publicum Europaeum (vol. 1, C. F. MÜLLER 2007) $61 \mathrm{ff}$.

${ }^{13}$ P. CRuZ Villalón in A. von Bogdandy et al. (eds.), Handbuch Ius Publicum Europaeum (vol. 1, C. F. MÜLLER 2007) 22. For the same regulation in the Netherlands: L. BESSELINK in A. vON BogDANDY et al. (eds.), HandbuchIusPublicumEuropaeum (vol. 1, C. F. MÜLLER 2007) 107-108.

${ }^{14}$ The long-standing US-American Non Delegation Doctrine is «moribund»: H. PÜNDER, 'Democratic Legitimation of Delegated Legislation: A Comparative View on the American, British and German Law' (2009) 58 International Comparative Law Quarterly 353, 358.

15 J. BATES, 'United Kingdom' in U. KARPEN (ed.), Legislation in European Countries (1996) 428, $438 \mathrm{ff}$. See also the British Regulatory Reform Act of 2001.

${ }^{16}$ A. Kimmel, 'Gesetzgebung und politisches System Frankreichs' in W. ISMAYR (ed.), Gesetzgebung in Westeuropa (VS Verlag für Sozialwissenschaften 2008) 229, 255.

${ }^{17}$ H. SCHNEIDER, Gesetzgebung (3rd edn., 2002) nos. $231 \mathrm{ff}$.

${ }^{18}$ W. ISMAYR (ed.), Gesetzgebung in Westeuropa (VS Verlag für Sozialwissenschaften 2008) 12. 
Science of Legislation (Legisprudence, Legistics, Legistique) does research on the complex process of drafting and approving laws and other norms and undertakes teaching of the matter, in order to improve practical legislative work. Legistics looks into the process from the legislative impulse to the decision-making process and to the implementation of the law, further on to the evaluation of the effects of that law and possible amendments as the starting point of a new regulation cycle. Legistics does so as (i) analysis of norms, (ii) as research and practice or organisation and procedure of legislation, (iii) further on by analyzing methods for policy and adequate goal-setting and choice of effective and efficient means of regulation, and (iv) with the intent to regulate on matters in a precise, clear, understandable form and by applying technical instruments for better regulation, like references, settlements or codifications, in order to keep the body of law small and transparent.

After the reception of the 'forgotten' science of legistics in the eighties of the 20th century, legislation theory and practice - similar to the sciences of administration and jurisdiction - developed as an interdisciplinary science of governmental functions and broadened its horizon by European aspects in the nineties. ${ }^{19}$ Since 1990 the perspective was enlarged again by looking at the law as an instrument in the arsenal of regulatory theory, as a tool of the benefit providing state, or at least benefit- guaranteeing- state, as well as the state protecting the environment. When the social-state-budgets shrank, economic rationality was desperately required: efficiency and Regulatory Impact Assessment (RIA) moved into the focus of interest in better regulation. In those days, Switzerland, the Netherlands, Sweden, Austria and Germany have made significant efforts in theory and practice of legislation. ${ }^{20}$ This progress could not have been made without the influence of the OECD. ${ }^{21}$

Les lois ne sont pas de pures actes de puissance; ce sont des actes de sagesse, de justice et de raison. Le législateur exerce moins une autorité qu'un sacerdoce. Il ne doit point perdre de vue que les lois sont faites pour les hommes et non les hommes pour les lois. ${ }^{22}$

${ }^{19} \mathrm{~W}$. Voermans and P. EiJlander, 'Working Out the Fundamentals for a Border-Crossing Post-Instrumental Doctrine on Legis-Prudence' in C.A. MORAND (ed.), Légistique Formelle et Matérielle, Formal and Material Legistic (1999) 47, 50 ff.; U. KARPEN, Gesetzgebungslehre: Neu Evaluiert / Legistics: Freshly Evaluated (2nd edn., 2008) $91 \mathrm{ff}$.

${ }^{20} \mathrm{Cf}$. the sixteen volumes of reports of activities of the International Association of Legislation (IAL), formerly the European Association of Legislation (EAL), which have been published since 1996 by Nomos Publishing.

${ }^{21} C f$. the Country Reports, published on the basis of independent 'Country Examinations', Series 'Better Regulation in Europe' (the last in 2010)

${ }^{22}$ Portalis, Discours preliminaire sur le Code Civil (first published 1804); reference by C. BERGEAL, Rédiger un Texte Normatif (6th edn., Berger-Levrault 2008) 295. 
Legistics is an interdisciplinary theoretical and practical science as well as a 'handicraft'. In order to better understand the law, its drafting and effects juridical sciences, economy, social sciences, philologies, information-theory and cybernetics cooperate in an interdisciplinary manner. The subjects of jurisprudence are legal norms and institutions. In this notion jurisprudence is a sector of humanities and cultural science. The law, however, is a tool of 'social engineering' and thus jurisprudence a social science as well. ${ }^{23}$

Legistics is a theoretical science. It is descriptive, applying the hermeneutical method of humanities. It writes and understands legal texts, using the empirical methods of social sciences. It makes research on the goals and efforts of legislation, describes actors and procedures of legislation, tries to understand the actual political will of the people as represented by democratic parliaments.

Legistics, however, is a practical science as well. It is prescriptive and normative. A practical science does not primarily accumulate knowledge but wants to direct actions. Legistics try to find directives, how to 'improve' laws. Roscoe Pound is of the opinion that academic teachers should look at practice: «Legal monks who pass their lives in an atmosphere of pure law, from which every worldly and human element is excluded, cannot shape practical principles to be applied to a restless world of flesh and blood. ${ }^{24}$

Legistics as a practical science strives at political rationality. It tries to understand politics as gaining and keeping power and influence in order to enable politicians to realise policies. As a practical science legistics uses the knowledge of ethics, political sciences and applies their measures and criterions to political action.

Finally, legistics deals with handicraft or even arts. In the end, arts consist of intuition, talent, gift, and these virtues could, in their core, not be taught and learnt. But doubts remain: «We hold these truths to be selfevident, that all men are created equal, that they are endowed by their Creator with certain unalienable Rights, that among these are Life, Liberty, and the pursuit of Happiness.»

These well-known words of the American Declaration of Independence are an outstanding piece of legislation, and G.K. Chesterton did not hesitate to evaluate it as 'great literature' ${ }^{25}$ It may well be that it is impossi-

${ }^{23} \mathrm{~K}$. ZWEIGERT and H. KÖTZ, Einführung in die Rechtsvergleichung auf dem Gebiete des Privatrechts (3rd edn., Mohr Siebeck 1996) 45.

${ }^{24} \mathrm{~K}$. ZWEIGERT and H. KöTZ, Einführung in die Rechtsvergleichung auf dem Gebiete des Privatrechts (3rd edn., Mohr Siebeck 1996) 242.

${ }^{25}$ See H. Caldwell, 'Can Legislation Rank as Literature?' in C. Stefanoǔ and H. XANTHAKI (eds.), Drafting Legislation: A Modern Approach (Ashgate 2008) $245 \mathrm{ff}$. 
ble to draft laws of that quality. However, one may and can train skills of good writing, transfer experiences; one can understand qualified legislation in a rational manner, as far as possible. That's what legistics tries to do.

\section{Good Governance, Better Regulation, Better Legislation}

The practical side of legislation, namely the policy elements of planning and decision-making in the legislative process, have been neglected for a long time in European legistics. It was left to Political Sciences. In the meantime this has changed. It is obvious that legitimation of the law does not come from rationality of its matter, but from democratic sources. Parliament and government as legislators need majority support of the people. At its best, rationality and majority coincide as a solid basis for implementing the law. If this is not the case, majority vote in politics takes precedence. ${ }^{26}$ This is one of the main reasons why legistics in recent times is much more interested in the broader approaches of 'good governance' and 'better regulation' - better policy. In the focus of 'better legislation' it cooperates in reducing quantity and improving quality of legislation.

In the definition of the World Bank of 2009:

We define governance as the traditions and institutions, by which authority in a country is exercised for the common good. This includes (1) the process by which those in authority are selected, monitored and replaced, (2) the capacity of the government to effectively manage its resources and implement sound politics, and (3) the respect of citizens and the state for the institutions that govern economic and social interactions among them. ${ }^{27}$

It remains, however, an open question, whether quantity and transparency of the European Union- and Member States-bodies of law can be addressed as 'good governance' today.

The term 'better regulation' is more oriented towards political management. The evaluation of states measures the steering capacity of governments and institutions of society on their way to democracy and social market economy. Legislation is just one instrument of regulation among

${ }^{26}$ C.A. Morand, 'Éléments de Légistique Formelle et Matérielle' in C.A. Morand (ed.), Légistique Formelle et Matérielle, Formal and Material Legistic (1999) 17, 37; G.J. VeERMAN, Over Wetgeving (2007) $155 \mathrm{ff}$.

${ }^{27}$ Reference by U. KARPEN, 'Good Governance' (2010) European Journal of Law Reform 16. See also A Sustainable Europe for a Better World: A European Union Strategy for Sustainable Development. Commission, 'A Sustainable Europe for a Better World: A European Union Strategy for Sustainable Development' (Communication) COM (2001) 264 final; Commission, European Governance (White Paper) (2001) COM 428 final. 
others, like (financial) support, subsidies, contracts and various forms of coordination and cooperation..$^{28}$

As 'better law-making', legistics strives at reducing the number of intransparent laws which impede implementation and to increase quality by improving efficacy, effectiveness, efficiency. In theory and practice there are many tools to reach these goals and get at 'better legislation'. Among them are better transparency, more participation, self-regulation by stakeholders, accelerated legislation procedures, increased RIA. The organs of the European Union in 2002 have adopted an Interinstitutional Agreement on better legislation, ${ }^{29}$ and the Commission since that time insisted on the following criteria: responsibility, proportionality, transparency, and legal certainty. ${ }^{30}$

Much has been written on the quantity of modern legislation. Undoubtedly, excessive legislation is a criterion of quality deficits, for laws which one cannot know or does not understand cannot be effectively implemented: «Woe onto you also, ye lawyers! For ye lade men with burdens grievous to be borne, and ye yourselves touch not the burdens with one of your fingers.»

This lament in Luke 11:46 should, in democratic times, be addressed to the legislator. G.C. Thornton hits the nail on its head: ${ }^{31}$

'Do it today. Tomorrow it may be illegal!' - This wisdom of a car bumper sticker observed in Queensland is a reminder of the alarming accumulation of statute law as month by month, year by year, lawmakers throughout the Commonwealth pile layer upon layer of new or amending laws. An increase in quantity is inevitably accompanied by an increased likelyhood of complexity and incomprehensibility.

This evaluation of legislation as a whole is shared in all countries, as referred to. It is true in particular for the legislative activities of the European Union. ${ }^{32}$ There is agreement on reasons for the acceleration of legis-

${ }^{28}$ Influential the annual 'Transformationsindex' of the Bertelsmann Foundation, the latest for 2010 (Gütersloh 2009). See also OECD, 'Regulatory Reform in Germany' [2003] GOV/ PUMA/REG(2003)1; OECD, Government at a Glance 2009 (OECD 2009) in particular 97 ff.; 'Mandelkern Group for Better Regulation: Final Report' (Europa, 13 November 2001) <http:// ec.europa.eu/governance/ better_regulation/documents/mandelkern_report.pdf> accessed 30 September 2012; U. KARPEN, 'Good Government Through Transparent Application of the Rule of Law' (2009) European Journal of Law Reform 213, $214 \mathrm{ff}$.

29 Inter-institutional Agreement of the European Parliament, the Council and the Commission on Better Law-making (I I A) [2003] O.J. C321.

${ }^{30}$ Commission, 'European Governance: Better Lawmaking' (Communication) COM (2002) 275 final.

${ }^{31}$ G.C. Thornton, Legislative Drafting (3rd edn.,Butterworths 1987) v.

${ }^{32}$ BMJ, Programm der Bundesregierung Bürokratieabbau und Bessere Rechtssetzung: Bericht zum Stand der Rechtsbereinigung (Bundesregierung 2009). As for EU legislation, see W. Robinson, 'Drafting EU-Acts: A View From the European Commission' in C. STEFANOǓ and 
lation: $:^{33}$ increase of public tasks in the welfare and intervention state, technology, juridification of many more areas of life, 'hunger for norms' of administration and the judiciary.

Consent, however, is lacking as far as instruments to cope with increasing quantity and decreasing quality of norms are concerned. Surely the maxim, attributed to Montesquieu, is true: «If you don't need to make a law, you may not make a law.» In fact Montesquieu did not write that. Possibly one has amalgamated some of his writings to this aphorism. Indeed, he writes that 'superfluous laws weaken necessary laws' and '[i]f in a law you don't need to make exceptions, it is much better, to make none'. ${ }^{34}$ All this is, however, an obvious starting point. In the following some further steps towards reducing the deluge of laws will be depicted.

As turning to the quality of laws, there is nothing like an 'ideal law', i.e. a law which, according to targets and efficacy, transparency and good wording, is perfect, which is drafted and adopted in a well-organised, speedy procedure and content- and form-wise meets all requirements. The drafter can, however, write a 'good' or 'relatively good' piece of legislation which regulates properly a new field of legislation or - with amendments - deletes recognised or recognizable deficits. ${ }^{35}$ Today it is widely accepted that constitution and law of a country establish standards for procedure, goals and form of laws. ${ }^{36}$ Recall only the principles of subsidiarity (Article 5(1) TEU, Article 23(1) Basic Law of Germany) and proportion-

H. XANThaKi (eds.), Drafting Legislation: A Modern Approach (Ashgate 2008) $177 \mathrm{ff}$. See also J.P. DUPRAT, 'The Recent Evolutions in French Legislative Practice: A Managerial Conception of Statutes' (2009) 50 Legislação: Cadernos de Ciência de Legislação 261;C. Bergeal, Rédiger un Texte Normatif (6th edn., 2008) nos. 1 ff.; Lord Justice THOMAS and R. WRIGHT, 'Lawmaking in England and Wales: Access to Justice' (2009) 50 Legislação: Cadernos de Ciência de Legislação 277, 278.

${ }^{33}$ W. ISMAYR (ed.), Gesetzgebung in Westeuropa (VS Verlag für Sozialwissenschaften 2008) $12 \mathrm{ff}$.

${ }^{34}$ Montesquieu and K. Weigend (ed.), Vom Geist der Gesetze (first published 1748, vol. 29, Philipp Reclam 1965) 405 ff.

${ }^{35}$ R. Hotz, MethodischeRechtssetzung (1983) 108.

${ }^{36}$ On Belgium, see P. POPELIER, 'Legislation in the 21st Century, Legitimate and Rational Law-making in a Context of Multilevel Governance' (2009) 50 Legislação: Cadernos de Ciência de Legislação 357; on Switzerland, see L. MADER, 'From the Struggle for Law to the Nurture of Law-making: Recent Efforts by the Swiss Confederation to Improve the Quality of Legislation' in: (2009) 50 Legislação: Cadernos de Ciência de Legislação 295, 296; on France, see O. JouAnJAn, 'Grundlage und Grundzüge Staatlichen Verfassungsrechts: Frankreich' in A. VON Bogdandy et al. (eds.), Handbuch Ius Publicum Europaeum (vol. 1, C. F. Müller 2007) no. 105; on the U.S.A., see L. TRIBE, American Constitutional Law (2nd edn., Foundation Press 1988) 70, 793, 859, 947 and 1682; Robert W. BENNETT in U. KARPEN (ed.), Legislation in European Countries (1996) 458 ff.; OECD, 'Guiding Principles for Regulatory Quality and Performance $(O E C D)<$ http://www.oecd.org/dataoecd/24/6/34976533.pdf> accessed 30 September 2012. 
ality (Article 5(1) TEU, perm. litig. of the German Constitutional Court (GCC) and the European Court of Justice (Court of Justice)). And undoubtedly rule of law in the meaning of transparency, unequivocal and clear language, effectiveness and efficiency is a constitutional mandate. One can no longer say that 'the legislator is in debt only of a law'. ${ }^{37}$ Even if one shares critical voices, that sovereignty of parliament is dominated by constitutional courts - 'Gulliver enchaîné' ${ }^{38}$ It does not help to classify research to constitutional quality standards of legislation as 'standards literature'.$^{39}$

Constitution and law provide quality standards for procedure, goals and contents as well as the textual form of legislation. The legislator in planning the procedure of a new law has to take into account that it is introduced on the proper level of legislation: European Union, Member State, (State in a Federation), local and municipal level. Furthermore, he must find the proper step in the hierarchy of norms: constitution, statutory law, delegated legislation or administrative directive? The stakeholders - political parties, groups, associations - must be included into the procedure and heard. There must be RIA, ex ante and ex post. These are the standards of structural and procedural due process. ${ }^{40}$

The principles of substantive and material due process direct the goals and instruments of the law. ${ }^{41}$ The law concretises normative directives of the constitution, in particular democracy, rule of law and social state principles, Human Rights (life, liberty, property). ${ }^{42}$

Finally, the legislator must take care that a well-structured draft is adopted, which is written in a clear (plain) language, and using references only to an extent that transparency, user-friendliness and anticipation of implementation and interpretation are not inhibited.

Tocqueville finally was not right when he stated, that it may be difficult to understand a law, but everybody can read it. Nobody can read the attachment to the (German) Social Security Code (Book V).

${ }^{37}$ K. SCHLAICH, 'Die Verfassungsgerichtsbarkeit im Gefuge der Staatsfunktionen' in Berichte und Diskussionen auf der Tagung der Vereinigung der Deutschen Staatsrechtslehrer zu Innsbruck vom 1. bis 4. Oktober 1980 (De Gruyter 1981) 99, 101.

${ }^{38}$ C.A. Morand (ed.), Légistique Formelle et Matérielle, Formal and Material Legistic (1999) 43.

${ }^{39}$ G.F. SChUPPERT, 'Gute Gesetzgebung' (2003) Zeitschrift für Gesetzgebung, Sonderheft $1,19 \mathrm{ff}$.

${ }^{40}$ L. TRIBE, American Constitutional Law (2nd edn., Foundation Press 1988) 679, 793, 859, 947, 1333 and 1672.

${ }^{41}$ ibid. ch. 17, in particular 1682.

${ }^{42}$ ibid. 689; C. A. MoRAND (ed.), Légistique Formelleet Matérielle, Formal and Material Legistic (1999) 40. 
The same is true for the authorisation to delegated legislation in the field of (European) food regulation. ${ }^{43}$

\section{Methods of Comparative Law}

Comparative Law is - as a comparison of law and legislation - an essential element of legistics, in particular in search of methods for better legislation. Comparative law is a comparison of structures. ${ }^{44}$ Comparative law analyzes the functions of (statutory) law in legal systems, as instruments of regulation, organisation, stabilisation and distribution. Comparative public law is shaped by its political character. ${ }^{45}$ This is particularly true for comparative constitutional law. Each Constitution has its peculiarities. To do detailed research leads into a thicket. It makes more sense to look at the types of states' organisation as well as provisions of state-goals - like the social welfare state - which are value-based. This is comparison of fundamental norms of constitutions. Both facets of constitutions - organisation and basic values - are directives for procedure as well as goals and means of legislation. Comparison of European and related constitutions focuses on horizontal separation of powers as main elements of rule-of-law constitutions as well as vertical arrangements in multi-layer systems: the individual state as well as supra- and international state systems.

There are various reasons for comparing constitutions. ${ }^{46}$ After all, law is language which may transfer cultures and ideas, in particular in learning and teaching. Exchange of legal ideas and law is peaceful interaction. From comparison of law one may develop 'bench marking'. In multi-layer-systems legal systems influence each other: European law influences national law and viceversa. Comparative law is an indispensable element of transformation of states. ${ }^{47}$ Comparative law arguments and observation of foreign and international court rulings are a fifth method of statutory interpretation, next to grammatical, systematic, historical and purposive interpretations. ${ }^{48}$ All of these reasons are useful for practical problems of law drafting.

${ }^{43}$ F. HuFEN, 'Über Grundlagengesetze' in G.F. SCHUPPERT (ed.), Das Gesetz als Zntrales Steuerungsinstrument des Rechtsstaates (1998) 20.

${ }^{44}$ I. HÄRTEL, Handbuch Europäische Rechtssetzung (Springer 2006) 6.

${ }^{45}$ B. WIESER, Vergleichendes Verfassungsrecht (2005) 27; U. KARPEN, Ausländisches öffentliches Recht und Rechtsvergleichung im Ausgang des 20. Jahrhunderts (2000).

${ }^{46} \mathrm{~W}$. Voermans, 'Styles of Legislation and Their Effects' in 32(1) Statute Law Review 38, 39; I. HÄrTEL, Handbuch Europäische Rechtssetzung (Springer 2006) 6.

${ }^{47}$ U. KARPEN, 'Das Grundgesetz als «Exportartikel»: Föderative Strukturen bei der Verfassungsreform in Südafrika, Bosnien-Herzegovina und Afghanistan' in R. PITSCHAS and A. UhLE (eds.), Wege gelebter Verfassung in Recht und Politik, Festschrift für Rupert Scholz zum 70. Geburtstag (2007) 615-636.

${ }^{48}$ A. WeBER, Europäische Verfassungsvergleichung (Verlag C.H. Beck 2010)11. 
Each legal system has its style. It is shaped by the constitutional type of the country - parliamentary or presidential government and so on - by the 'legal family' it belongs to - common law, civil law, others - the legal techniques, the tradition and the subject which the law regulates on. The style of law and legislation which shapes the legal culture of a country is part of the country's general culture, i.e. tradition, language, history, government, politics and society. ${ }^{49}$

The constitutional type, which frames all constitutional systems, as referred to in this paper, is that of the democratic rule-of-law state, the free democratic order, the democratic liberal constitution. This type of constitution rests on the principle of human dignity, tolerance and plurality. ${ }^{50}$ Human Rights, as a core of that constitutional type of rule-of-law state, are part of the legal tradition of all European Union Member States. ${ }^{51} \mathrm{Ar}-$ ticle 6(3) TEU reads as follows:

Fundamental rights, as guaranteed by the European Convention for the Protection of Human Rights and Fundamental Freedoms and as they result from the constitutional traditions common to the Member States, shall constitute general principles of the Union's Law.

The model of this type of constitution is built on four pillars: Rule of law, representative democracy (with here and there some elements of direct democracy), parliamentary government and the highest position of constitutional law in the hierarchy of norms, ${ }^{52}$ the latter of which is often guaranteed by constitutional courts. In reality, modern constitutions, as referred to, are based on the principles of Rule of law, Human Rights, Solidarity, Democracy and (partly) Federalism as an instrument supporting pluralism, vertical structure of government and decentralisation. ${ }^{53}$

${ }^{49}$ P. HÄBERLE, Europäische Verfassungslehre (7th edn., 2011). See also K. ZWEIGERT and H. KÖTZ, Einführung in die Rechtsvergleichung auf dem Gebiete des Privatrechts (3rd edn., Mohr Siebeck 1996) 68; on the development of US-American legal culture, see L. TRIBE, American Constitutional Law (3rd edn., Foundation 2000) 1332.

${ }^{50}$ C. MöLlERS, Gewaltengliederung, Legitimation und Dogmatik im Nationalen und Internationalen Vergleich (2005).

${ }^{51}$ B. WIESER, VergleichendesVerfassungsrecht (2005) 105; L. TRIBE, American Constitutional Law (3rd edn., Foundation 2000) 118 and 132: «The model of separated and divided powers, vertical and horizontal (...).» On the rule of law, see Report of the Secretary-General, 'The Rule of Law and Transitional Justice in Conflict and Post-conflict Societies' (2004) U.N. Doc. S/2004/616; C. MöLlERS, Gewaltengliederung, Legitimation und Dogmatik im Nationalen und Internationalen Vergleich (2005) 208.

${ }^{52}$ P. CRuZ Villalón in A. VOn Bogdandy et al. (eds.), Handbuch Ius Publicum Europaeum (vol. 1, C. F. Müller 2007) no. $29 \mathrm{ff}$.

${ }^{53}$ A. von Bogdandy et al. (eds.), Handbuch Ius Publicum Europaeum (vol. 1, C. F. Müller 2007) no. $73 \mathrm{ff}$. 
Constitutions of the 'Western Constitutionalism' type in general have two parts: an organic and a dogmatic one. The first one regulates on organisation and procedures of government. The latter consists of Human Rights and some more principles which are linked to Rule of law: in Europe, e.g. the concept of the Social State. «In any case, time is seen to have passed when this part of the constitution had been looked at to be the second one after the organic constitution. ${ }^{54}$ From Human Rights, Rule of Law and Social State some constitutions have developed standards for goals and means of legislation. ${ }^{55}$

The style of law and legislation is mainly characterised by the 'legal circle', the 'legal family' it belongs to. Legislation in European countries, including European legislation, is shaped by civil law on the continent and common law in England. ${ }^{56}$ Civil law in France, Italy, Spain, Germany, Austria, Switzerland and other countries tends to abstraction, generalisation, prefers deduction and a broad purposive interpretation (teleological method). The ideal of the drafters is codification, the codex. In contrast, common law - in England, in the U.S.A. and (partly) in Canada as well is based on precedents which have been developed in long-standing tradition, even from medieval times. Precedence and case law are slowly enriched by comprehensive Parliamentary Acts (Statutes). The judge decides on the case, he has to solve: «We'll cross the river when we come to it.» Interpretation of legal texts is narrow, sticks to the words and follows 'long-lasting court decisions' (stare decisis).

The well-known English expert of legislation, Sir William Dale ${ }^{57}$ compared the styles of English and Continental Statutes. His opinion: English laws are long and intransparent; there are long sentences and paragraphs, many details, few principles. The legislator prefers the indirect approach to the subject and uses the 'method of subtraction': 'subject to', 'provided that'. Dale detects that the legislator is hesitating to make clear decisions. The legislator works centrifugal. He tries to escape from a central regulation of the matter to definitions and directives for interpretation. There are too many and too long catalogues, chains of references. Many statutes

54 P. Cruz Villalón in A. VON Bogdandy et al. (eds.), Handbuch Ius Publicum Europaeum (vol. 1, C. F. MÜLLER 2007) no. 91.

${ }^{55}$ G. Biaggini, 'Grundlagen und Grundzüge Staatlichen Verfassungsrechts: Schweiz' in A. von Bogdandy et al. (eds.), Handbuch Ius Publicum Europaeum (vol 1, C.F. MüLlER 2007) no. 54 and 56.

${ }^{56}$ K K. ZWEIGERT and H. KÖTZ, Einführung in die Rechtsvergleichung auf dem Gebiete des Privatrechts (3rd edn., Mohr Siebeck 1996) 271 ff. See also R. DAVID and G. GRASMANN (eds.), Einführung in die großen Rechtssysteme der Gegenwart (2nd edn., 1988) 79 ff. and $431 \mathrm{ff}$, who also refer to the Nordic Family of Law and the particularities in Dutch Law.

${ }^{57}$ W. DALE, Legislative Drafting: A New Approach (Butterworths 1977) $331 \mathrm{ff}$. 
'copy out' European Directives. On the continent, however, Dale finds clear statutes, regulations, starting from principles, broad approaches, conceptual legal thinking, clear definitions at the first appearance of legal terms.

Going into details of national styles of legislation, Sir William is of the opinion that French legislation rests on clear principles, forms of legislation and the language are transparent. The French legislator prefers logical development of regulation and economical language.

Swedish laws are characterised by a language, which strives at being understandable to the laymen. Technical terms are to be found in a preamble or preface or in an appendix, not in the law itself. German legislation starts from a clear principle at the top of the law, then details are regulated on in great precision. German laws are often long, but always in good systematic order. The language is always rather complicated.

It is, however, remarkable that, notwithstanding different styles of legislation and methods of interpretation - inductive in common law, deductive in civil law - legal solutions of problems are pretty much the same, or at least very similar. ${ }^{58}$ The growing integration into European law supports this development.

It adds to the convergence of legislative styles that in many fields of regulation statutory law solutions are more or less one of the requirements of the subject matter. ${ }^{59}$ This is particularly true for tax, social security, building, environmental and food legislation: many laws in the area of culture and education are shaped by the federal organisation of the relevant countries. Another reason for growing similarities of statutory legislation is a sort of 'silo-mentality' of drafters or drafter teams in the ministries. They work in similar styles in all countries. That is true for national states as well as for supra-national and international levels, where one would find the well-known 'clubs of experts' on a given subject. ${ }^{60}$

\section{Unification of Law}

The transition from equalisation of law in style and contents to unification is proceeding step by step, is inevitable and desirable. This transi-

${ }^{58}$ K. ZWEIGERT and H. KÖTZ, Einführung in die Rechtsvergleichung auf dem Gebiete des Privatrechts (3rd edn., Mohr Siebeck 1996) 38.

${ }^{59}$ K. VOn Beyme, Der Gesetzgeber (1997) 65; U. KARPEN, I. BREUTZ and A. NünKE, Gesetzescheck: Die Gesetzgebung der Großen Koalition in der ersten Hälfte der Legislaturperiode des 16. Deutschen Bundestages (2005-2007) (2007) 46 ff. and 166 ff.

${ }^{60}$ U. KARPEN, 'Reform des Öffentlichen Rechts und Good Governance: Das Beispiel Ägypten' in V. MEHDE et al. (eds.), Staat, Verwaltung, Information: Festschrift für Hans Peter Bull zum 75. Geburtstag (2011) 625-638. 
tion is supported by two facts: the opening of states and their constitutions to supra- and international organisations as well as its effects: the emergence of European and International Unitary Law. ${ }^{61}$

Constitutional provisions allow for streaming in of supranational and international law into national law, ${ }^{62}$ even transfer elements of sovereignty onto transnational levels. ${ }^{63}$ One important goal of that emergence of 'open states' is to foster peaceful cooperation.

The growing together of legal and non-legal standards is a key element of a Common European Law. As the European Union itself, the member states are 'communautés de droit' ${ }^{64}$ with legal principles, statutory laws, rules, standards, best practices 'general principles common to the laws of the member states' (Article 340(3) TFEU). Probably the single most important factor of this process are the court rulings of the Court of Justice and the European Court of Human Rights (ECtHR). Essential parts of this common European (constitutional) law are democracy, rule of law, the social state, the main legal basis of economic and technical development, ${ }^{65}$ and primarily Human Rights. The body of law of the member states grows together, by transfer of law of neighbouring states ${ }^{66}$ and parallel transformation of European law (directives), not to forget legal literature and teaching.

Similarly, international standards, principles, rules, best practices are developed. Issues of health-protection, new techniques (Information and Communication Technology, Bio-Technology and so on), trafficking in human beings and drugs, illegal migration are international challenges which require political and legal cooperation. According to rule-of-law principles,

${ }^{61}$ E. von CAEMmerer, P. SCHLeChtriem and H. StOll (eds.), Kommentar zum Einheitlichen UN-Kaufrecht (CISG) (2nd edn., 2005) Einleitung unter III. On respectively harmonisation and unification of law, and European Law, see J. KROPHOLLER, Internationales Einheitsrecht, Allgemeine Lehren (1975) $17 \mathrm{ff}$. and $35 \mathrm{ff}$.

${ }^{62}$ W. Voermans in C.A. Morand (ed.), LégistiqueFormelleetMatérielle, Formal and Material Legistic (1999) 59.

${ }^{63}$ See arts. 23-26 and 59(10) Basic Law for the Federal Republic of Germany; The UK European Communities Union Act 1972; The Swiss practical approach to follow European Law 'in autonomy'.

${ }^{64}$ P. Cruz Villalón in A. von Bogdandy et al. (eds.), Handbuch Ius Publicum Europaeum (vol. 1, C. F. Müller 2007) no. 58; U. KARPEN, 'Grundrechte, due process und die Reform des Verwaltungsverfahrens in Transformationsländern: Das Beispiel Kroatien' in M. SACHS and H. SiEKMANN (eds.), Der Grundrechtsgeprägte Verfassungsstaat, Festschrift für Klaus Stern zum 80. Geburtstag (2012) 1083-1096; I. HÄrTEL, Handbuch Europäische Rechtssetzung (Springer 2006) 6; K. ZWEIGERT and H. KÖTZ, Einführung in die Rechtsvergleichung auf dem Gebiete des Privatrechts (3rd edn., Mohr Siebeck 1996) 3.

${ }^{65}$ I. VAN DER VLIES, 'Perspectives of International Legislation' in L. MADER and C. MOLL (eds.), The Learning Legislator (Nomos 2009) 33.

${ }^{66}$ As in Croatia (Administrative Procedures), Macedonia (Delegated Legislation), and Egypt (Law of Civil Service). 
instruments to deal with these problems must be primarily parliamentary laws. The civil law countries have practiced that procedure since long. Common law countries are not in a position to manage this new situation with case law. They need to make statutory law. They need to revise the perception that law is judge-made law and that statutory legislation is just an 'ensemble of islands in the ocean of case law'. ${ }^{67}$ Universal rules develop: in contract law, social security law, labour law, and so on. Legistics has to follow, because its basis is independent of particularities of legal and legislative cultures. For legistics legislation, as inspired by comparative law, is at stake. Legistics has to develop concepts of qualified legislation and insights into knowledge and capabilities which improve quality of drafting laws everywhere. ${ }^{68}$

\section{PROCESS OF LEGISLATION}

\section{Competences, Organisation and Procedure of Legislation}

In comparative law perspective one must ask 'who' the legislator is, be it in a multi-layer-system or in the frame of a national state constitution. The same question applies to procedure of legislation. Three principles of organisation have to be taken into account.

Firstly, there is vertical separation of powers. In member states legislative competences are centralised or left to the centre and subnational units, like the Länder in Germany, the States in the United States on the one hand, and Cantons (in Switzerland), Regions (in Spain) or other autonomous institutions on the other. In the association of countries there are three layers of legislation: national, supranational and international.

Secondly, there is horizontal separation of powers. On the national level three powers are actors in legislation: legislative, executive and finally the (constitutional) judiciary. In the 'supranational (European) or international constitutional organizations' separation of powers is not fully developed yet. In the European Union, progress has been accomplished as far as involvement of the Parliament is concerned. In fact, 'the legislators' are Council, Commission and Parliament, the 'executive' is the Commission and the 'judiciary' is the European Court of Justice. Instead of 'separation of powers' one may - as Härtel does ${ }^{69}$ - talk of an 'institutional

${ }^{67}$ K. ZWEIGERT and H. KöTZ, Einführung in die Rechtsvergleichung auf dem Gebiete des Privatrechts (3rd edn., Mohr Siebeck 1996) 27.

${ }^{68}$ H. XANTHAKI, 'National vs. Universal Training for Drafters, und DUNCAN BERRY: A visionary of training in Legislative Drafting' in: Commonwealth Association of Legislative Counsel: The Loophole (2011) $18 \mathrm{ff}$.

${ }^{69}$ I. HÄRTEL, Handbuch Europäische Rechtssetzung (Springer 2006) 12. 
balance' of the organs. The same - also not fully unfolded horizontal separation of powers - is even more true for international organisations. ${ }^{70}$

The legislative procedure as being the centre of government is characterised by cooperation of all branches of government in the interest of the whole body of the state. For the national level there are the principles of cooperative federalism, for the European Union Article 4(3) TEU reads: «Pursuent to the principle of sincere cooperation, the Union and the Member States shall, in full mutual respect, assist each other in carrying out tasks which flow from these treaties.»

Cooperation, however, obviously is needed in the horizontal direction, should the whole unit work. It is, therefore, legitimate to speak of a network of decision-making processes. ${ }^{71}$

That far toorganisational and procedural structure of legislation. These three problems are intensively discussed currently in comparative legistics. Firstly, the shift of competences in multi-layer systems; secondly, the loss of participation of parliaments in systems as dominated by government in member states and multi-layer systems, and, thirdly, intransparency and deficits of participation in the legislative process.

\section{Legislation in Multi-level Systems}

Our states are more and more 'open' to Union law, the law of the European Convention of Human Rights (ECHR) and international law of pacts and conventions. ${ }^{72}$ There is an emerging transnational network, in particular a European Constitutional, ${ }^{73}$ and Administrative Space. ${ }^{74}$ The more national governments break up, sometimes disintegrate, the more important are coordination, consultation and cooperation. ${ }^{75}$ The binding force of international law is weaker, but there is an ever-closer integration of national and supranational law with international treaties, conventions, civil and political rights acts, ${ }^{76}$ and international legal standards (part of the 'globalization').

${ }^{70}$ C. MöLlERS, Gewaltengliederung, Legitimation und Dogmatik im Nationalen und Internationalen Vergleich (2005) 253.

${ }^{71}$ F. BECKER, Kooperative und konsensuale Strukturen in der Normsetzung (2005).

72 P. Cruz Villalón in A. VON Bogdandy et al. (eds.), Handbuch Ius Publicum Europaeum (vol. 1, C. F. MÜLLER 2007) no. 87; A. WEBER, Europäische Verfassungsvergleichung (Verlag C.H. Beck 2010)396.

${ }^{73}$ Cf. art. $34 \mathrm{~V}(3)$ TFEU.

74 Art. 41 ECHR. For the Netherlands, see I. van der Vlies, 'Perspectives of International Legislation' in L. MADER and C. MOLL (eds.), The Learning Legislator (Nomos 2009) 34. G. BIAGgINI, 'Grundlagen und Grundzüge staatlichen Verfassungsrechts: Schweiz' in A. VON Bogdandy et al. (eds.), Handbuch Ius Publicum Europaeum (vol 1, C.F. Müller 2007) no. 84.

75 I. HÄRTEL, Handbuch Europäische Rechtssetzung (Springer 2006) $24 \mathrm{ff}$.

${ }^{76}$ Cf. art. 21 TEU; art. 26 GG. 
Public tasks are accomplished primarily on a national level. Here, organs decide according to constitutional provisions on manner and extent of externalizing these tasks. As far as domestic distribution of tasks is concerned, in most countries - as referred to here - competences are split and partly attributed to central as well as deconcentrated or decentralized lower levels.

Unitarian states, which are only deconcentrated, are Norway, Sweden, Iceland, Hungary, Poland and the Netherlands. ${ }^{77}$

Federal systems are Germany, Austria, Switzherland, Belgium, the USA and Canada. Austrian Federalism is weak, ${ }^{78}$ the German one much stronger. In Switzerland, ${ }^{79}$ the subsidiarity principle is taken very serious$l y$, in the $\mathrm{USA}^{80}$ the states exist in very different and vivid subnational constitutional spaces.

There is, however, also a form of political decentralization which is reduced in view of a full-fledged Federal State. This applies to the (Italian) Regional State, ${ }^{81}$ the (Spanish) Union of Autonomies, ${ }^{82}$ and the devolution of public tasks ${ }^{83}$ in the United Kingdom. Beyond all these structures in centralized as well as decentralized states is territorial autonomy of municipalities, counties and villages.

Distribution of competences for legislation varies very much. There are exclusive, concurrent, frame and completing competences. Supremacy of Federal Law (like in art. 31 of the German Basic Law) is not given in every federation. The same is true for a general assumption for the decentralized units, as in the EU: «Competences not conferred upon the Union in the Treaties remain with the Member States» or «Except as otherwise

${ }^{77}$ A. WeBER, Europäische Verfassungsvergleichung (Verlag C.H. Beck 2010)349.

${ }^{78}$ E. Wiederin in A. von Bogdandy et al. (eds.), Handbuch Ius Publicum Europaeum (vol. 1, C. F. Müller 2007) no. 78.

${ }^{79}$ G. BIAGGINI, 'Grundlagen und Grundzüge staatlichen Verfassungsrechts: Schweiz' in A. von Bogdandy et al. (eds.), Handbuch Ius Publicum Europaeum (vol 1, C.F. MÜLler 2007) no. $42 \mathrm{ff}$.

${ }^{80}$ L. Tribe, American Constitutional Law (3rd edn., Foundation 2000) 795 ff.; J.B. FORDHAM et al., Materials on Legislation (4th edn., Foundation Press 1982) 694 and 740.

${ }^{81} \mathrm{M}$. Dogliani and C. Pinelli in A. von Bogdandy et al. (eds.), Handbuch Ius Publicum Europaeum (vol. 1, C. F. MÜLLER 2007) no. 38; O. JouANJAN, 'Grundlage und Grundzüge Staatlichen Verfassungsrechts: Frankreich' in A. vON BOGDANDY et al. (eds.), Handbuch Ius Publicum Europaeum (vol. 1, C. F. MÜLLER 2007) no. 97 ff.

${ }^{82}$ M.M. Guerrero in A. von Bogdandy et al. (eds.), HandbuchIusPublicumEuropaeum (vol. 1, C. F. MÜLler 2007) no. 36 and 73.Autonomies are Basque, Catalonia and Galicia.

${ }^{83}$ M. Loughlin in A. VON Bogdandy et al. (eds.), Handbuch Ius Publicum Europaeum (vol 1, C.F. MÜLLER 2007) no. 58. Cf. the Scotland Act of 1998 and the Government of Wales Act of 1998, which attributed legislative competences to Edinburgh and Cardiff within the frame of Westminster Legislation. The Autonomy of Northern-Ireland was reorganized in 1998 as well. 
provided or permitted by this Basic Law, the exercice of state powers and the discharge of state functions is a matter of the Länder». ${ }^{84}$ There are adversary trends: ${ }^{85}$ unitarisation on the one hand, decentralization on the other. In all vertically structured systems sociocultural unity in a shrinking world is a predominant public goal. On the other hand, democratic participation is easier in a world which the citizens can oversee.

'Cooperative Federalism', 'implied powers' of the centre, Interstate Compacts: 'Unified legislation' is a pragmatic approach in all decentralized systems ('diversity in unity'). ${ }^{86}$ There is, however, an adversary trend in the United Kingdom, Spain and France.

The European Union, which is the level placed above the national legislator, is a 'state in being', ${ }^{87}$ whether a confederation (the German Constitutional Court even avoids this term, notwithstanding 'Federation', and uses 'Staatenverbund' instead, which is a 'connection of states' ${ }^{88}$ a supranational organization, transnational federation or how one prefers to call it. EU law gets more and more the vigor of constitutional law, mainly through the decisions of the European Court of Justice and the European Court of Human Rights. Legislative competences of the Union and other legal acts are laid down in art. 288 ff. TFEU. ${ }^{89}$ European Parliament and Council are according to art. 290 TFEU, similar to art. 80 German Basic Law - entitled to authorize the Commission to legislate, but only under strict preconditions of delegation. The transfer of EU law to the member states generally requires a parliamentary law; in the United Kingdom and Portugal a piece of delegated legislation might be sufficient. The European Court of justice holds that EU law takes precedence over law of the member states..$^{90}$ This opinion is not shared by the majority of the Member States' constitutional courts. This is true even for states which, in general, don't allow for scrutiny in statutory laws. ${ }^{91}$

In all countries, which are referred to, an ever-increasing internationalization of legislation can be observed. Many forms of cooperation, gateways for 'opening' national law to supranantional and international legal

${ }^{84}$ Art. 5(2) TEU;art.30 Basic Law for the Federal Republic of Germany.

${ }^{85}$ W. ISMAYR (ed.), Gesetzgebung in Westeuropa (VS Verlag für Sozialwissenschaften 2008) 46.

${ }^{86}$ J.B. FordHAM et al., Materials on Legislation (4th edn., Foundation Press 1982) 694: Interstate Compacts, uniform and model legislation, reciprocal legislation («Runaway Puppy Act»).

${ }^{87}$ A. WeBER, Europäische Verfassungsvergleichung (Verlag C.H. Beck 2010)11.

${ }^{88}$ Cf. BVerfGE 123, 267 (348).

${ }^{89}$ See alsoJ. GÜNDISCH and P. MATHIJSEN, Rechtsetzung und Interessenvertretung in der Europäischen Union(Boorberg 1999).

${ }^{90}$ Cf. I. HÄrTEL, Handbuch Europäische Rechtssetzung (Springer 2006) 6.

${ }^{91}$ P. CruZ Villalón in A. vON Bogdandy et al. (eds.), Handbuch Ius Publicum Europaeum (vol. 1, C. F. MÜLLER 2007) no. 88. 
orders and 'international law-friendly norms' support this development, e.g. in Germany, ${ }^{92}$ Austria, Switzerland, ${ }^{93}$ the United Kingdom and, in particular, in the Netherlands. One may speak of 'legislation as being determined by international law' in view of these laws, ${ }^{94}$ which are adopted for applying international agreements as well as other legal acts of supranational organizations or are initiated by international legal acts. The UNO, ILO, WTO, OECD, OSCE, the Bologna Process are to be taken into account in this respect. ${ }^{95}$ These organizations, in general, don't produce binding law, as 'statutes', but soft law. The ILO, for example, releases two sorts of legal acts: conventions and recommendations. These are norms of a general character in matters of labour and social security law, which set standards and 'international customary law'. Undoubtedly, for the work and functioning of these organizations principles of 'due process' are applicable.Very often they have General Conferences, which are parliamentary-like, furthermore Conferences of Ministers (executive) and decision-making bodies of courts-character, like the WTO with Panel and Appellate Body to solve legal disputes. ${ }^{96}$ Here one can observe the evolution of structures of the constitutional state.

Multi-level legislation as part of multi-level governance raises problems for state and supranational as well as international organizations: techniques of balancing 'powers' in vertical and horizontal perspective, clarification of priorities and hierarchies, a clear order of competences, due process-principles for organizations and procedures, clear intersections between states and supra- and international organizations, which have to be 'constitutionalized' step by step. ${ }^{97}$

\section{Organisation of Legislation and Separation of Powers}

Legislation is primarily a responsibility of parliament and its members, elected representatives of the people. The initiative for law-making rests in most countries with the government. This is an element of separation of

${ }^{92}$ Arts. 23-26 and 59(2) Basic Law for the Federal Republic of Germany.

${ }^{93}$ Development from 'introverted national state to world-open, cooperative Constitutional State'. See R. Rhinow, Die Bundesverfassung 2000 (Helbing \& Lichtenhahn 2000) 355

${ }^{94}$ G.F. SCHUPPERT (ed.), Das Gesetz als Zentrales Steuerungsinstrument des Rechtsstaates (1998) 71.

${ }^{95}$ C. MöLlers, Die Drei Gewalten (Velbrück 2008) 194 ff.; C. MöLlERS, Gewaltengliederung, Legitimation und Dogmatik im Nationalen und Internationalen Vergleich (2005) 204, 209 and 216.

${ }^{96}$ C. Möllers, Die Drei Gewalten (Velbrück 2008) 207.

${ }^{97}$ P. POPELIER, Legislation in the 21st Century: Legitimate and Rational Law-making in a Context of Multilevel Governance in(2009) 50 Legislação: Cadernos de Ciência de Legislação 357, 364; A. WEBER, Europäische Verfassungsvergleichung (Verlag C.H. Beck 2010)402. 
powers, which should be called a 'balance of powers' in the European Union and international organisations. Close cooperation of parliamentary government and parliament, mostly dependence of government of parliamentary majority, is the core of the parliamentary system. Parliament adopts formal laws (like the budget) and formal-material laws (statutory laws). The principle of statutory reservation requires a formal-material law for any administrative action, which touches upon human rights. ${ }^{98}$ Some countries have organic laws (France, Spain, Italy, Croatia), which in the hierarchy of norms rank in-between constitution and statutory law. Delegated legislation requires in most countries an authorisation by statutory law.

In countries with direct-democratic elements the people participate in adopting constitutional and statutory laws, partly may initiate legislation. Switzerland has the strongest form of referenda. ${ }^{99}$ Instruments of direct democracy are additions to parliamentary action. However, without a parliamentary basis and support a referendum-democracy cannot work. In some countries there are obligatory and facultative referenda; ${ }^{100}$ in some countries plebiscites are possible, which are not binding on other state organs, like in Switzerland, Denmark and Italy. To initiate a referendum is very often a 'threat' in political debates. Anyway, referenda are appreciated increasingly as an innovative procedure for fostering participation of the citizens in decision-making.

Parliament is the democratic representation of the people. ${ }^{101}$ From the floor of the house initiatives may originate. Parliament adopts laws and other proposals (like international treaties). It can authorise government to adopt sublegal norms. In 'essential matters' (like in particular restrictions of human rights) rule of law and democratic principles require decisions by statutory laws (statutory reservation, réserve de loi). Parliament has rights to interpellate and to require presence of government. Every parliament has structures for division of work (like committees, caucuses, parliamentary services and so on). Last amendments of primary legislation the European Union are shaped by more intensive participation of the European Parliament in the decision-making process of the Union. ${ }^{102}$

${ }_{98}$ A. WEBER, Europäische Verfassungsvergleichung (2010) 192.

${ }^{99}$ G. BIAGGINI, 'Grundlagen und Grundzüge staatlichen Verfassungsrechts: Schweiz' in A. vON Bogdandy et al. (eds.), Handbuch Ius Publicum Europaeum (vol 1, C.F. Müller 2007) no. 59.

${ }^{100}$ W. ISMAYR (ed.), Gesetzgebung in Westeuropa (VS Verlag für Sozialwissenschaften 2008) 34 .

${ }^{101}$ In England: «The Queen in Parliament.» See J. BATES, 'United Kingdom' in U. KARPEN (ed.), Legislation in European Countries (1996) 432.

${ }_{102}$ A. WeBER, Europäische Verfassungsvergleichung (Verlag C.H. Beck 2010) 259; A. MAURER, Parlamentarische Demokratie in der EU: Der Beitrag des Europäischen Parlaments und der nationalen Parlamente (2002); W. VOERMANS, 'Is the European Legislator after Lisbon a Real Legislator?' (2009) 50 Legislação: Cadernos de Ciência de Legislação 391. 
Parliament in many countries has just one chamber ${ }^{103}$ other national constitutions establish a second chamber. ${ }^{104}$ Some countries abolished bicameral systems for reasons of transparent democratic legitimation and better functional efficiency. ${ }^{105}$ Second chambers often are regional-federal representation; otherwise they represent professional, social or economic groups of society or are elements of a corporate state. ${ }^{106}$ There are symmetric and asymmetric bicameral systems. In symmetric systems both chambers participate equally in the legislative process, ${ }^{107}$ in latter ones the second chamber has only suspensive vetorights. ${ }^{108}$ In many countries there are joint committees of both houses, ${ }^{109}$ which may compromise in case of divergent opinions of the houses. The German Committee (Article 53a BL) may serve as an example. ${ }^{110}$

There is no unanimous opinion, whether the bicameral system has advantages or is dispensable. ${ }^{111}$ Regional representations certainly are an instrument to avoid majorisation of smaller versus larger units. They exercise intra-organ control. Bicameral systems shall enlarge rationality of deliberation and quality of decisions. On the other hand, some voices say that two chambers cause a time-consuming duplication of deliberations and decisions. This might be used for delaying important projects without really gaining more quality.

Government, due to its responsibility to set guidelines for policy initiates most drafts. It needs laws (and the budget) for running the country. The United States have a monistic presidential system, European countries dualistic governments, where the executive is vested in a president and a government. This may be a parliamentary system - as in Germany, Italy, Austria and so on - or a mixed presidential-parliamentary system - like in France. ${ }^{112}$

${ }^{103}$ As in Denmark, Sweden, Portugal, Hungary, Turkey, see P. CRUZ VILlalón in A. VON Bogdandy et al. (eds.), Handbuch Ius Publicum Europaeum (vol. 1, C. F. MüLler 2007) no. 115.

${ }^{104}$ As in Germany (Bundesrat or Federal Council), Austria (Bundesrat or Federal Council), Switzerland (Ständerat or Council of Cantons), United Kingdom (House of Lords), France (Senate), USA (Senate), Italy (Senato), and Spain (Senado).Cf. P. CRUZ VILlalón in A. VON BoGDANDY et al. (eds.), Handbuch Ius Publicum Europaeum (vol. 1, C. F. MüLleR 2007) no. 116.

105 Denmark, Sweden and Iceland.

${ }_{106}$ As the Irish Senate.For the abolishment of the Bavarian Senate (an assembly of the corporate state), see U. KARPEN (ed.), Role and Function of the Second Chamber (1999). The House of Lords is no longer an assembly of hereditary nobility only.

107 As in Switzerland(partly), in Italy and Germany (partly)

${ }^{108}$ France, Great Britain, the Netherlands, Germany (partly).

${ }^{109}$ In Belgium, Italy and so on.

${ }^{110}$ A 'Dark Room of legislation' and a 'totally undemocratic institution', as claimed by D. BuRCHARD and M. PUTZER (2011) 26(1) ZeitschriftfürGesetzgebung 68.

111 W. ISMAYR (ed.), Gesetzgebung in Westeuropa (VS Verlag für Sozialwissenschaften 2008) $37 \mathrm{ff}$.

${ }^{112}$ Mostly the Head of Government or Government at all are elected by Parliament (not so in the Netherlands!), in the first case with (as in Germany and Spain, see M.M. Guerrero in 
The Basic Law of Germany does not have a catalogue of the governmental functions ${ }^{113}$ - in contrast to other constitutions - but undoubtedly planning and coordination of state functions and policy making is a governmental responsibility, which covers predominantly directing legislation.

Delegated legislation by government by far outnumbers statutory legislation ${ }^{144}$ and deals with details of laws, as enacted.

Laws in general are drafted in the ministries and are approved by cabinet. In the United Kingdom the Office of Parliamentary Counsel in the Prime Minister's Office realises the legislative programme of government in drafts; in Sweden, the main work of writing texts is done by Royal Commissions. Switzerland discusses for a long time to establish a Central Draft Service, but finally, however, abolished this idea due to egoism of resort ministries. ${ }^{115}$

Courts and other state organs have a 'negative legislative competence' in the sense that they are entitled to declare a law void or to refuse to apply it in a case. This is a 'juridification of legislation', 'la juridicisation progressive des règles de méthode législative'. ${ }^{116}$ The judicial review of laws is a tool of protection of the constitution. It is a curb-stone of precedence of the constitution over all law and as such one of the most important elements of constitutionalism. ${ }^{117}$

There are models of concentrated and diffuse supervision of laws. In the first case only one constitutional organ is entitled to declare laws void as conflicting with the constitution. According to the Austrian model of

A. VON Bogdandy et al. (eds.), Handbuch Ius Publicum Europaeum (vol. 1, C. F. MÜLLER 2007) no. 65) or without the competence to set policy-guidelines (like in Austria).

${ }^{113}$ Not so in Switzerland (art. 180 BV) or France (art. 20 I of the Constitution). As 'motor' of integration the European Commission has the monopoly of legislative initiative. The Council has no initiative competence, although it is the 'institutional eye of the needle' of the legislative cycle. See W. Wessels, 'Gesetzgebung in der Europäischen Union' in W. ISMAYR (ed.), Gesetzgebung in Westeuropa (VS Verlag für Sozialwissenschaften 2008) 658.

${ }^{114}$ In Spain, Sweden, Poland, Italy, Switzerland, Germany and the EU (Art. 290(2) TFEU). According to narrow guidelines of goals and content, in France partly as competence to adopt secondary law with the force of statutes (ordonnances), in Great Britain (statutory instruments) with partly subsequent control by parliament.

${ }^{115}$ For the United Kingdom, J. BATES, 'United Kingdom' in U. KARPEN (ed.), Legislation in European Countries (1996) 452; For Sweden, see B. EDQUIST in U. KARPEN (ed.), Legislation in European Countries (1996) 404; W. DALE, Legislative Drafting: A New Approach (Butterworths 1977) 98; for Switzerland, see G. MüLLER, Elemente einer Rechtssetzungslehre (2nd edn., 2006) 227.

116 C.A. Morand (ed.), LégistiqueFormelleetMatérielle, Formal and Material Legistic (1999) 39.

117 A. WeBER, Europäische Verfassungsvergleichung (Verlag C.H. Beck 2010)327; P. CRUZ Villalón in A. VON Bogdandy et al. (eds.), Handbuch Ius Publicum Europaeum (vol. 1, C. F. Müller 2007) no. 7. 
1920 usually this is a Constitutional Court. This is also the model of the German Constitutional Court, which has been adopted by many countries (e.g. Italy, Hungary, Spain, South Africa) ${ }^{118}$ Other countries implemented models of diffuse supervision of laws. In this case every court in a case may refuse to implement a legal norm due to contradiction to the constitution. In Switzerland, e.g. review of statutory legislation is explicitly excluded, in respect of the instruments of control of laws by the people (referenda). ${ }^{119}$ In other countries review of legislation is rather weak, like in the Netherlands and the United Kingdom. ${ }^{120}$ One may say that there are models of abstract, preventive review - like in Germany or Sweden ${ }^{121}$ and other models of concrete, case-linked review. Since Marbury v. Madison $^{122}$ the Supreme Court of the United States claims authority of concrete review of law. The same is true for the European Court of Justice and the European Court of Human Rights. ${ }^{123}$

\section{Legislation in the Regulatory Cycle}

Laws are drafted, adopted and implemented in a multi-step procedure, in which all constitutional organs, as mentioned before, participate.

The main steps of legislating are: impulse, analysis of the problem, policy-setting, definition of the targets and instruments of regulation, drafting, deliberation and adoption of the draft in parliament, implementing,

${ }^{118}$ In Spain Tribunal Constitucional (M.M. GUERRERO in A. VON BOGDANDY et al. (eds.), Handbuch Ius Publicum Europaeum (vol. 1, C. F. MÜLlER 2007) no. 68 ff.), in Hungary the Solyom-Court, and in Italy the Corte Costitutionale (M. Dogliani und C. PINELli in A. VON Bogdandy et al. (eds.), Handbuch Ius Publicum Europaeum (vol. 1, C. F. Müller 2007) no. 35). In France the Conseild'État is just an advisory organ of government; the ConseilConstitutionnel, however, is entitled to an abstract review of statutes (O. JOUANJAN, 'Grundlage und Grundzüge Staatlichen Verfassungsrechts: Frankreich' in A. VON BoGDANDY et al. (eds.), Handbuch Ius Publicum Europaeum (vol. 1, C. F. MÜLlER 2007) nos. 88 ff.).

119 G. BiagginI, 'Grundlagen und Grundzüge staatlichen Verfassungsrechts: Schweiz' in A. von Bogdandy et al. (eds.), Handbuch Ius Publicum Europaeum (vol 1, C.F. MüLleR 2007) no. $67 \mathrm{ff}$.

${ }^{120}$ In the Netherlands according to art. 120 Grondwet review of statutes is not permitted; however the Raad van Stade is consulted for each draft; in the United Kingdom since the Constitutional Reform Act of 2005 the Supreme Court may decide that EU-Law takes precedence over United Kingdom-Law (M. Loughlin in A. VON BogDANDY et al. (eds.), Handbuch Ius Publicum Europaeum (vol 1, C.F. Müller 2007) no. 80); on the other hand a sub-committee of the parliament decides on the compatibility of drafts with the Human Rights Act. Otherwise review is diffuse.

${ }^{121}$ By the Legislative Council, see H.H. Vogel, in A. von BogdANDY et al. (eds.), Handbuch Ius Publicum Europaeum (vol 1, C.F. MÜLLER 2007) no. 112.

${ }^{122}$ Marbury v. Madison 5 US 137 (1803).

${ }^{123}$ A. WEBER, Europäische Verfassungsvergleichung (Verlag C.H. Beck 2010)336 ff. 
monitoring of implementation, amendment (if necessary) in a new procedure. Then the regulatory cycle is completed. In short, there are four phases of legislating: initiative and drafting, deliberation and adoption, implementation and enforcement, control and amendment - drafting, enacting, implementation and monitoring.

The basic structures of the legislative process are part of the constitution. Details are regulated on in rules of procedure of parliament and government. The German Federal Constitutional Court (FCC) in some decisions established directives for good legislative procedures: to check the facts in detail, to establish a sound prognosis, to balance the interests, to carefully monitor the impact of regulation, to induce amendments, if necessary. ${ }^{124}$ This catalogue is applicable for the modern legislator, ${ }^{125}$ and applies for European legislation as well. ${ }^{126}$

In view of rule of law and legislation as well as obvious deficiencies of representative democratic governance there are two main challenges for the legislative process: transparency, ${ }^{127}$ and participation. ${ }^{128}$ Modern information and communication techniques make distribution of knowledge and facts easy. These new possibilities are only partly exhausted. Procedures of preparing and adopting laws in government and parliament are often extremely accelerated. The language and form of the products is poor and indigestible - in all: intransparent. ${ }^{129}$ Examples are security-legislative acts after $9 / 11$ or financial packages to 'save the Euro' as well as 'exit from nuclear energy'-legislation after Fukushima. Better participation should bring in the expertise and opinion of scientists and 'intermediate agents', like interest-groups, autonomous (communal) bodies, the media and other stakeholders. ${ }^{130}$

${ }^{124}$ A. Burghart, Die Pflicht zum guten Gesetz (Duncker \& Humblot 1996).

${ }^{125}$ W. Dale, Legislative Drafting: A New Approach (Butterworths 1977) 334 ff.; J.V. Sullivan, How our laws are made, House of Representatives, Washington (2007); J.B. FORDHAM et al., Materials on Legislation (4th edn., Foundation Press 1982) 256 ff.; H. BodE, Das Gesetzgebungsverfahren in Schweden und Deutschland (2007).

${ }^{126}$ I. HÄRTEL, Handbuch Europäische Rechtssetzung (Springer 2006) 334.

${ }^{127}$ U. KARPEN, 'Instructions for Law Drafting' (2008) 10 European Journal of Law Reform $163,213 \mathrm{ff}$.

${ }^{128}$ U. KARPEN, 'Instructions for Law Drafting' (2008) 10 European Journal of Law Reform 163, $213 \mathrm{ff}$.

${ }^{129}$ OECD, Bessere Rechtssetzung in Europa: Deutschland (OECD 2010) $73 \mathrm{ff}$.

${ }^{130}$ A. ANGERmanN and B. SitTEMAnN, Bürgerschaftliches Engagement in den Mitgliedsstaaten der Europäischen Union: Auswertung und Zusammenfassung aktueller Studien (2011) 7-9; C. BERGEAL, Rédiger un Texte Normatif (6th edn., Berger-Levrault 2008) 206. The Netherlands believe in a 'culture of consultation', and have hundreds of of bodies, which have been reduced by law of 1995 to a few (Woestijnwetot 'Law of the desert'). See L.F.M. BESSELINK in A. vON BogDANDY et al. (eds.), HandbuchIusPublicumEuropaeum (vol 1, C.F. MÜLLER 2007) no. $128 \mathrm{ff}$, who refers to 'backstage-consultations' (at 128). 
Initiative for legislation in most countries originates primarily in government, may, however, be taken by Parliament, First or Second Chamber, parliamentary committees, citizens, regional parliaments, governmental commissions, enquètes and so on. Amendments may be required - after negative results of evaluation of implementation - by line ministries, the courts, European Union legislation, interest groups, associations, and so on. ${ }^{131}$ In Switzerland initiatives may be taken by referenda. ${ }^{132}$ Impulses come from government policy statements or agreements of coalition-governments. The work of the drafters takes place in line-ministries, in the United Kingdom in the Office of Parliamentary Counsel, in France often in the Sécrétariat Général du Gouvernement, in Italy in a central committee for coordination of legislation. ${ }^{133}$ This is true for Canada as well. ${ }^{134}$ The European Commission has the monopoly for initiatives in Council and Parliament. The Commission is the drafter. The checking of the draft by a National Regulatory Control Council - an independent body of experts, like in Germany - leads to substantial improvements of drafts.

Deliberations and adoption of the draft are the responsibility of parliament. In general, in-between first, second and third reading in the plenary, deliberations in detail take place in the committees. ${ }^{135}$ To enlarge knowledge and participation there may be hearings and enquêtes. The draft afterwards - according to the constitution of the country - may be transferred to the Second Chamber. If decisions of both chambers diverge, in Germany, Belgium, France and the United States there is a Joint Committee; ${ }^{136}$ a similar organ mediates in the European Union between the European Parliament and the Council. ${ }^{137}$ Austria, Italy and the United Kingdom do not know a Joint Committee. After having finalised the procedure, the law is signed - in general by the head of state - and published.

Then the law is implemented. Effective implementation is the predominant quality criterion of a law. If it is not executed and - if necessary enforced, law and state loose trust. Execution may require delegated legis-

${ }^{131}$ W. ISMAYR (ed.), Gesetzgebung in Westeuropa (VS Verlag für Sozialwissenschaften 2008) 19 ff.; I. VAN DER VLIES, 'Perspectives of International Legislation' in L. MADER and C. MOLL (eds.), The Learning Legislator (Nomos 2009) 34. International treaties conventions, and compacts are to be added. For the U.K., $c f$. the Cabinet Committee on the Legislative Programme.

${ }^{132}$ G. BIAGginI, 'Grundlagen und Grundzüge staatlichen Verfassungsrechts: Schweiz' in A. VON Bogdandy et al. (eds.), Handbuch Ius Publicum Europaeum (vol 1, C.F. Müller 2007) no. 61.

${ }^{133}$ A. Cervati in U. KarPen (ed.), Legislation in European Countries (1996) 260.

134 R.C. BERGERON, Essaies sur la Rédaction Législative (1999).

135 In the United Kingdom the ad hoc-Committees (standing committees) or permanent committees, for monitoring or special issues (select committees). See W. ISMAYR (ed.), Gesetzgebung in Westeuropa (2008) 31.

${ }^{136}$ Or 'Conference Committee'.

137 Art. 294(10) TFEU. 
lation, administrative directives, administrative acts or planning. Transformation and implementation of European Union law is in general is an institutional and procedural matter of member states, which are autonomous and hence distribute competences to levels, organs and institutions according to their own constitutions. ${ }^{138}$ The commission administers the European Union budget. As 'watchdog of the treaties' the Commission has responsibility for ensuring the Union-wide effective implementation of European Union regulations. ${ }^{139}$

There are different institutions which monitor the effective implementation of laws. It is primarily parliament itself which has to keep its 'legal production under control', by obliging government to regularly report on the effects of the law, by 'sunset legislation' or by regular consolidation of laws. Finally, there is supervision of laws by (constitutional) courts, ${ }^{140}$ by experience of administrative bodies, as implementing the law, as well as by lawyers and, e.g. law school teachers, who have to deal with these laws in practice and theory. Sweden, Germany and Poland have - partly more than one ${ }^{141}$ - offices of ombudsmen.

If RIA demonstrates that the law does not have the intended effects or that unintended side-effects occur, the legislator is called upon to amend the law or to adopt a new one.

\section{GOALS, INSTRUMENTS AND EVALUATION OF LEGISLATION}

\section{Legislation in the Regulatory Cycle}

According to the question of legistics, 'who, why, how', the focus is now on the 'why' of legislating. This part will deal with the purposes of a legal project, the programme (policy), the intent (objective, legislative targets, goals) of a law and the instruments to realise it. Finally, the quality of the law is at stake, standards and evaluations of quality ${ }^{142}$ (substance,

${ }^{138}$ I. HÄRTEL, Handbuch Europäische Rechtssetzung (Springer 2006) 15.

${ }^{139}$ W. ISMAYR (ed.), Gesetzgebung in Westeuropa (VS Verlag für Sozialwissenschaften 2008) $657 \mathrm{ff}$.

${ }^{140}$ For Italy, see M. Dogliani and C. Pinelli in A. von Bogdandy et al. (eds.), Handbuch Ius Publicum Europaeum (vol. 1, C. F. Müller 2007) no. 117: for Spain, see M.M. Guerrero in A. vON BogdANDY et al. (eds.), Handbuch Ius Publicum Europaeum (vol. 1, C. F. Müller 2007) no. 43.

${ }^{141}$ See H.H. Vogel in A. VON Bogdandy et al. (eds.), HandbuchIusPublicumEuropaeum (vol. 1, C. F. MÜLlER 2007) no. 115: ombudsman for defence, equality, handicapped, nondiscrimination against ethnical origin and so on.

${ }^{142}$ For Switzerland, see G. MüLLER , Elemente einer Rechtssetzungslehre (2nd edn., 2006) 41; for Germany, see A. Burghart, Die Pflicht zum guten Gesetz. (Duncker \& Humblot 1996) 116 ff.; for the U.S.A., see L. TRIBE, American Constitutional Law (2nd edn., Foundation Press 
merits, substantial due process). Legistics is interested in policy-making, the decision-making process, value-criteria for 'good', effective and efficient legislation. Legistics asks the question, which normative directives for legislation are vested in the constitution. In other words: what is the content of the legislative procedure, as dealt with in sect. II.

\section{Political Aims, Goals and Instruments of Legislation}

Legislation - contentwise - follows a multi-step-procedure. The impulse that a law may be needed and should be drafted is followed by a thorough analysis of the facts, the current legal situations and its deficits. Then the main lines are drawn, what should happen, which the coming legal situation shall be. That is policy-making. From these starting points one looks at possible means to solve the emerging problems, evaluates them and makes choices, which are expedient and realistic (concretizing the goals). Finally the appropriate instruments are provided.

The first step in preparing legal action must be a political directive of government (policy). The political course, the red rope of the project should be determined. It is vital that the legal project fits into the governmental programme.

Such a political directive reacts to a problem-impulse, where ever this originates. To put it simply: «What is the matter? Why is governmental action requested? Where is the problem?» ${ }^{143}$ For a thorough diagnosis one needs to ask detailed questions concerning evolution, data, statistics, surveys of actors and stakeholders. The diagnosis should follow a 'political checklist': ${ }^{144}$ Is a law required, in fact? Who are the stakeholders? Which sociological, economic, cultural factors have to be taken into account? After having analyzed the problem policy must determine the desirable legal situation: which are its main factors? Which developments should be avoided? ${ }^{145}$ Only after the check of the past and the future situation legislative work will start in detail.

As this policy phase must not only evaluate the circumstances of the envisaged legislative project, but has to take into account challenges, chances and limits of political action in a wider sense - governmental

\footnotetext{
1988) ch. 17; for Belgium, see P. PoPELIER, De wet: Juridisch bekeken, (Die Keure 2004); K. MEßERSCHMIDT, Gesetzgebungsermessen (2000).

${ }^{143}$ Swiss Gesetzgebungsleitfaden: Leitfaden für die Ausarbeitung von Erlassen des Bundes (3rd edn., Bundesamt für Justiz 2007) 113.

${ }^{144}$ U. KARPEN, 'Instructions for Law Drafting' (2008) 10 European Journal of Law Reform $163,167 \mathrm{ff}$.

${ }^{145}$ Swiss Gesetzgebungsleitfaden: Leitfaden für die Ausarbeitung von Erlassen des Bundes (3rd edn., Bundesamt für Justiz 2007) 113.
} 
guidelines, compromises and consent, elections, budget and so on - it is important to distinguish policy-making as the first step from following ones, like choice of targets and instruments. That is the case in many countries. ${ }^{146}$ In some countries special units in the governmental central office are responsible for policy development. ${ }^{147}$

Normative directives of the constitution have to be taken into account: the social state, and proportionality principles, necessities of economy, education and research as governmental tasks, support to disadvantaged groups of society and so on. In particular, a feeling for 'the manageables' is required. To bring it to a point: «Policy-making is not a topic for lawyers.» ${ }^{148}$

Within the policy-frame one then considers possibilities of solving the problem. This means in fact - if a law is indispensable - setting the goals of that law. One has to decide on the concept of the law, which are the contents of provisions, who are the addressees, whether the law is directly applicable or requires instruments for implementation, like sublegal acts, contracts and so on.

In general the legislator chooses instruments of causal steering of behaviour of economy, society, administrative agencies. In times of growing scepticism versus 'planning and steering' the legislator more often chooses directives. The law then is binding, as to the results to be achieved, but leave choice of measures, forms and method to the authorities, which implement the law (as in Article 288(3) TFEU). The targets, however, are often vague and sometimes even contradictory. ${ }^{149}$ The latter is true for the (German) laws on nuclear energy, on protection against harmful effects on the environment and the building law. The goal of the law is often mentioned in the preamble, mostly in the arguments, often, however, in form of directive norms, as in the Finnish Comprehensive School Act: ${ }^{150}$

146 According to art. 34 v-vi of the French Constitution a Program-Act defines the goals for the legislator, namely in view of the budget. In the USA the State of the Union address of the President is a Political Program (J.B. FordhAm et al., Materials on Legislation (4th edn., Foundation Press 1982) 256).

${ }^{147}$ The Polish Government on the basis of a law of 1996 and a Governmental Decision of 2002 established a Legislative Center in the Prime-Ministers Office, which on the basis of 'principles' of the statute, as planned, deals with coordination of political issues. Note also the 'Better RegulationUnit' in the German Federal Chancellery. For the Netherlands this is the Integrated Policy Framework, in the United Kingdom the Cabinet Office. $C f$. C. KNIK, M.W. BAUER and M. ZIEGLER, Optimierungsmöglichkeiten vorausschauender Politikgestaltung (Zukunft Regieren, Bertelsmann Stiftung 2006). In the European Commission the Directoriat of the General Secretariat sets Policy, see Commission, 'European Governance' (White Paper) (2001) COM 428 final, 6.

${ }^{148}$ K. VON BEYME, Der Gesetzgeber (1997) 73 ff.

${ }^{149}$ K. VON BEYME, Der Gesetzgeber (1997) 62.

${ }^{150}$ A. KIVUVUORI in U. KARPEN (ed.), Legislation in European Countries (1996) 155. 
The comprehensive school shall aim at raising its pupils to be well-balanced, physically and mentally fit, responsible, independent, creative, co-operative and peace-loving human beings and members of society. The comprehensive school shall bring its pupils (...) The teaching and other activities (...) the promotion of the equality between sexes.

Government would and should not immediately decide to make a law if other instruments are available for solving the problem. ${ }^{151}$ Government can, e.g. chose benefiting, stimulating as well as prohibiting or even punishing measures ('carrots and sticks'). ${ }^{152}$ The state can cooperate with society or groups of it (co-regulation) or leave the problems to be solved by the stakeholders themselves (self-regulation). In these cases agreements are made as well as goal and limit marks formulated or licenses and certificates edited.

If basically it is decided that a legal regulation is required, it is necessary to choose an option for attacking the problem: cause- or system-oriented, punctual or comprehensive, preventive or repressive? ${ }^{153}$ Furthermore, the best level of regulation has to be chosen: Is it necessary to make a statutory law or is a sublegal regulation sufficient? Does one need a general regulation or a very detailed one? Which is finally the content of regulation: command or inhibition (with sanctions?), authorisation or suggestion? As far as sanctioned inhibitions are concerned, the French Minister of Justice is of the opinion, 'queces sanctions sont trop nombreuses pour être effectivement utilisées' ${ }^{154}$ There are forms of symbolic legislation, which strive at having an educational effect: hints and indications, information, warnings, 'shop-window laws', for instance concerning protection of environment, waste-morals and so on. ${ }^{155}$ Such provisions are to be found in constitutions as well. This is a transition field to soft law which contains non-regulatory measures, like distinguishing marks and tokens, codes of conduct which originate from nongovernmental actors.

${ }^{151}$ Swiss Gesetzgebungsleitfaden: Leitfaden für die Ausarbeitung von Erlassen des Bundes (3rd edn., Bundesamt für Justiz 2007) 126 ff.

${ }^{152}$ L. TRIBE, American Constitutional Law (2nd edn., Foundation Press 1988) 1718.

${ }^{153}$ Swiss Gesetzgebungsleitfaden: Leitfaden für die Ausarbeitung von Erlassen des Bundes (3rd edn., Bundesamt für Justiz 2007) 127.

${ }^{154}$ C. Bergeal, Rédiger un Texte Normatif (6th edn., Berger-Levrault 2008) no. 165.

155 J. LÜDEMAnN, Edukatorisches Staatshandeln (2004); H.G. HenNEKE, 'Verfassungsänderungen zwischen Placebo-Effekten und tagespolitisch motivierten Einzelfallregelungen' [1990] Zeitschrift für Gesetzgebung 1, 25. 


\section{Evaluation of Legislation}

The constitution of the democratic rule of law-state includes material and procedural principles for legislation. ${ }^{156}$ Laws require democratic legitimation, must conform to subsidiarity and proportionality (Art. 5 TEU). The procedure of legislation must guarantee transparency, should be participative and based on scientific rationality. ${ }^{157}$ The contents of laws must be oriented to public welfare. ${ }^{158}$ It should apply constitutional values like social, ecologic, cultural state targets. A law must be effective and efficient. In a formal sense a law should be as simple as possible, formulated in a clear, plain language and coherent in structure. ${ }^{159}$

Subsidiarity and proportionality are to be obeyed on all steps of approaching legal goals, formulating contents and choosing instruments for implementation. Policy of legislation follows political programs and necessities of the day. Goals and instruments may be measured against three criteria: ${ }^{160}$ conformity with constitution and law, effectiveness and trust.

The most important criterion of quality of a statutory law is conformity with the body of law of the country. The piece of law has to observe the organic constitution and international law but also the dogmatic constitution (structural principles and Human rights section of the constitution) and to realise as much as possible the value system of it. Democracy and rule of law in member states' constitutions are in conformity with European standards. But also Human Rights as core of the material national constitution are vested in the Charter of Fundamental Rights of the European Union and in the European Court of Human Rights. ${ }^{161}$ The same is true for the United Kingdom: The Human Rights Act of 1998 is embedded into the Fundamental Rights System of Europe. ${ }^{162}$ Principles of state functions

156 Commission, 'European Governance' (White Paper) (2001) COM 428 final; Commission, Better Regulation: Simply Explained (European Communities 2006); OECD, Bessere Rechtsetzung in Europa: Deutschland (OECD 2010); I. HÄRTEL, Handbuch Europäische Rechtssetzung (Springer 2006) 21; Lord Justice THOMAS and R. WRIGHT, 'Lawmaking in England and Wales: Access to Justice' (2009) 50 Legislação: Cadernos de Ciência de Legislação 277, 288: 'principles-based legislation' in Great-Britain.

157 A. Burghart, Die Pflicht zum guten Gesetz (Duncker \& Humblot 1996) $123 \mathrm{ff}$.

${ }^{158}$ L. TRIBE, American Constitutional Law (2nd edn., Foundation Press 1988) 1365.

159 I. HÄRTEL, Handbuch Europäische Rechtssetzung (Springer 2006) 22 ff.

${ }^{160}$ J.D. PELlEY, 'Penser la Loi: Introduction a un Démarche Méthodique' in C.A. Morand (ed.), Légistique Formelle et Matérielle, Formal and Material Legistic (1999) 81, 93 ff.

${ }^{161}$ O. JOUANJAN, 'Grundlage und Grundzüge Staatlichen Verfassungsrechts: Frankreich' in A. VON Bogdandy et al. (eds.), Handbuch Ius Publicum Europaeum (vol. 1, C. F. MÜLleR 2007) no. 108 .

${ }^{162}$ M. Loughlin in A. Von Bogdandy et al. (eds.), Handbuch Ius Publicum Europaeum (vol 1, C.F. Müller 2007) no. 84. For Switserland, see G. MüLLER, Elemente einer Rechtssetzungslehre (2nd edn., 2006) $4 \mathrm{ff}$. 
and basic targets to attain are valid in all countries. The 'social state' may not in all countries be as 'value-loaded" 163 as in Germany, to that end, that individual claims for subsidies may be brought to governmental agencies. However, Article 117(2) of the Italian Constitution, as adopted of the law $3 / 2001$, requires from the legislator to 'fix the essential standards (livelli essenziali) of civil and social law payments'. ${ }^{164}$ Everywhere the state has to guarantee for the minimum material requirements of individual freedom, of 'development of personality' (Article 2(1) German Basic Law). ${ }^{165}$ Some constitutional directives may be interpreted as 'inherent in the nature of things', e.g. in nuclear energy law, in infrastructure or financial regulation. Not always definite goals of legislation may be derived from constitutions. This fact is, however, not a good reason to overlook the standard and value setting of the constitution.

Three important criteria of a qualified law are efficacy, effectiveness, efficiency $^{166}$ (the 'three E's'). A law has a high level of efficacy if it when implemented - comes closest to the legislator's intent. ${ }^{167}$ The seatbelt-fastening duty, e.g. was intended to reduce accidents with lethal or severely injuring consequences. As far as one knows, the belt has that effect. A law, moreover, is effective, ${ }^{168}$ if it is implemented, executed and obeyed by as many addressees as possible. The seat-belt-provision is plausible and complied with by most drivers. There remain - of course - sociological and psychological questions why this is true more or less in different countries. Efficiency ${ }^{169}$ - thirdly - is economic rationality, a positive cost-result (input-output) relation. The regulation is efficient if the result - reducing the number of severe traffic accidents-, is accomplished cheaper than with other measures, like better road-building or increased

${ }^{163}$ O. JOUANJAN, 'Grundlage und Grundzüge Staatlichen Verfassungsrechts: Frankreich' in A. VON Bogdandy et al. (eds.), Handbuch Ius Publicum Europaeum (vol. 1, C. F. MÜLleR 2007) no. 109.

164 M. Dogliani and C. Pinelli in A. VON Bogdandy et al. (eds.), Handbuch Ius Publicum Europaeum (vol. 1, C. F. Müller 2007) no. 102. Italy has a long tradition in this field, e.g. as far as minimum-wages are concerned.

165 U. KARPEN, Die Unterscheidung von Staat und Gesellschaft als Bedingung der rechtsstaatlichen Freiheit [1986] Juristische Arbeitshlätter 299, 302.

${ }^{166}$ Ulrich KARPEN, 'Folgenabschätzung für Gesetze und Richterrecht' in V. RIEBLE (ed.), Folgenabschätzung im Arbeitsrecht (2007) 13, 22.

167 OECD, Cutting Red Tape, Why Is Administrative Simplification So Complicated: Looking Beyond 2010 (OECD 2010) 98.

168 A. FlÜCKInger, 'Effectiveness: A New Constitutional Principle' (2009) 50 Legislação: Cadernos de Ciência de Legislação 183. The principle of effectivity is as a duty of the state laid down in Art 170 of the Swiss Constitution and art. 24 I of the French Constitution (with Constitutional Law of 23 July 2008).

169 E. Wiederin in A. VON Bogdandy et al. (eds.), Handbuch Ius Publicum Europaeum (vol. 1, C. F. MÜLlER 2007) no. 97 refers to the Constitutional litigation. 
railway-transport of cars. This seems to be the case. This does not exclude, however, alternative (legal) actions, so that more input - like road-building or/and speed limits and railroad transport - leads to a more effective, more significant reduction of severe accidents.

All three principles are facets of proportionality which is an element of rule of law. ${ }^{170}$ Effectivity of law requires stability, limited quantity and transparency of law, reduction of bureaucracy and deregulation. ${ }^{171}$ Citizens, economy and administration need to trust in continuity of the law. In this sense 'routine' is desirable. Trust is an important resource of stability, which combats frequent legislation to amend, adjust, repair law as enacted - trust contrasts a 'motorized legislator'. ${ }^{172}$ Many opinions favour deregulation:

However, the same government has failed both in terms of improving production techniques and, more importantly, in avoiding the ,schizophrenic legislator' model of previous governments who legislate hundreds of laws that are never implemented and are even revoked before they are enforced. ${ }^{173}$

Undoubtedly, reduction of 'legalisation' in all European states is a mandate of the time. ${ }^{174}$ Combating the deluge of laws is an aim of debureaucratisation. Instruments of New Public Management, ${ }^{175}$ devolution, decentrali-

${ }^{170}$ K. Sовотта, Das Prinzip Rechtsstaat, Verfassungs- und Verwaltungsrechtliche Aspekte (1997) 143, 200; U. KARPEN, 'Bedingungen der Effizienz des Rechtsstaates' [1992] Juristische Arbeitshlätter 70, 71.

${ }^{171}$ C.f. n 2, U. KARPEN, 'Draft Law on General Administrative Procedures of the Republic of Croatia' (2012) 60 JöR NF 431; U. KARPEN, 'Grundrechte, due process und die Reform des Verwaltungsverfahrens in Transformationsländern: Das Beispiel Kroatien' in M. SACHS and H. SiEKMANN (eds.), Der Grundrechtsgeprägte Verfassungsstaat, Festschrift für Klaus Stern zum 80. Geburtstag (2012) 1083-1096

172 U. KARPEN, I. BREUTZ and A. NÜNKE, Gesetzescheck: Die Gesetzgebung der Großen Koalition in der ersten Hälfte der Legislaturperiode des 16. Deutschen Bundestages (20052007) (2007) 2002; P. POPELIER, Rechtszekkerheid als Beginsel voor Behoorlijke Regelgeving (1997) 35 ff.;OECD, Cutting Red Tape, Why Is Administrative Simplification So Complicated: Looking Beyond 2010 (OECD 2010) 99.

${ }^{173}$ N. GaroupA, 'Improving Legislation: A Note of Pessimism' (2009) 50 Legislação: Cadernos de Ciência de Legislação 153. See also C. BERGEAL, Rédiger un Texte Normatif (6th edn., 2008) n. 9.

${ }^{174}$ W. ISMAYR (ed.), Gesetzgebung in Westeuropa (VS Verlag für Sozialwissenschaften 2008) 13.

175 For a critical analysis of the New Public Management-methods, see W. DRECHSLER, 'The Re-Emergence of «Weberian» Public Administration after the Fall of New Public Management' [2005] Halduskultuur 94; J. PIERRE and B. RothSTEIN, 'Reinventing Weber: The Role of Institutions in Creating Social Trust' in P. LAGREID and T. CHRISTENSEN The Ashgate Research Companion to New Public Management (Ashgate 2010) 407. 
sation, co-regulation contribute to that end. Many states - among them Germany - did set up special programmes for better administration. ${ }^{176}$

\section{Regulatory Impact Assessment}

To improve rationality of legislation methods of RIA have been introduced. ${ }^{177}$ One measures and assesses the intended and not-intended impacts of a law, be they financial, bureaucratic or other ones, be they impacts in the economic, administrative and social sector, i.e.in the citizen's sphere. RIA of a draft law generally is done prior to adoption (prospective, ex ante), also concurrent in the process of parliamentary deliberations in committees and the plenary and after implementation (retrospective, ex post), the latter ones for monitoring and possibly amending purposes. RIA started in the 1980's of the 20th century with 'checklists', which should be worked off at the beginning of drafting and then spread over governments, with multiform advice by Dutch experts. ${ }^{178}$

Ex ante RIA is done by the institutions which initiate the draft or by independent authorities. Concurrent RIA is the responsibility of all parliamentary organs, including the scientific parliamentary staff. Ex post RIA is a matter of everybody who has to implement, obey or otherwise handle

${ }^{176}$ For the Netherlands, the United Kingdom, Denmark and Germany, see the report of the (National Regulatory Control Council: Normenkontrollrat, Internationale Erfahrungenbeim Bürokratieabbau (Normenkontrollrat 2008). More on the work of the independent Council of Germany, see the Annual Reports 2007-2010, P. Costanzo, 'La semplificazione normativa nell'ordinamento italiano' (2009) 50 Legislação: Cadernos de Ciência de Legislação 343. For the EU, see Commission, 'Better Regulation for Growth and Jobs in the European Union' (Communication) COM (2005) 97 final.

${ }^{177}$ C. BÖHRET and G. KONZENDORF, Handbuch Gesetzesfolgenabschätzung (GFA) (2001); U. KARPEN and H. HOF (eds.), Wirkungsforschung zum Recht IV, Möglichkeiten einer Institutionalisierung der Wirkungskontrolle von Gesetzen (2003); Bertelsmann Stiftung, Handbuch zur Messung von Regulierungskosten (Bertelsmann Stiftung 2009); U. KARPEN, 'Gesetzesfolgenabschätzung in der Europäischen Union' (1999) 124 Archiv des öffentlichen Rechts 400;OECD, Cutting Red Tape, Why Is Administrative Simplification So Complicated: Looking Beyond 2010 (OECD 2010); Bertelsmann-Stiftung, International Regulatory Reform Congresses, 2007-2011.

178 2003-2007 Programm Administrative Burdens und Standard-Kosten-Modell (SCM), 2007-2011, erweitert zum Erfüllungsaufwand-Programm. Cf. C. RADAELLI, How to Learn from the International Experience: Impact Assessment in the Netherlands - Final Report (University of Exeter, Centre for European Governance 2010); on France, see J.P. DuPRAT, 'The Recent Evolutions in French Legislative Practice: A Managerial Conception of Statutes' (2009) 50 Legislação: Cadernos de Ciência de Legislação 261, 305; on Germany, see C. BÖHRET and G. KONZENDORF, ModernerStaat - ModerneVerwaltung: LeitfadenzurGesetzesfolgenabschätzung (Bundesministerium des Innern 2006); on the EU, see 'Better Regulation Impact Assessment' (EUROPA, 2 March 2009) <http://ec.europa.eu/governance/better_regulation/impact_en.htm> accessed 30 September 2012. See also I. HÄRTEL, Handbuch Europäische Rechtssetzung (Springer 2006) $334 \mathrm{ff}$. 
the law, e.g. in teaching and research. Deficiencies of legislation as well as high costs for implementation are reported by enterprises, administrative bodies and the media.

Ex ante RIA, which in some countries obligatorily must be part of the arguments of the law, in the Netherlands is done by the Adviescollegeverminderingadministratievelasten (ACTAL). This institution is a kind of model for the German National Regulatory Control Council (NKR), which has been established in 2006; in 2011 its competences have been enlargened. ${ }^{179}$ The council is a 'watchdog' of cost-effective legislation. ${ }^{180}$ The Swedish Regelrädet works in a similar manner. In the United States ex ante RIA is done in the Congressional Budget Office (CBO). ${ }^{181}$ Moreover, the US Office of Management and Budget (OMB) is part of the White House. In the United Kingdom the British Better Regulation Executive is part of the Department for Business, Enterprise and Regulatory Reform. And there is a Government Independent Regulation Policy Committee. The European Commission in 2007 established a High Level Group of Independent Stakeholders on Administrative Burdens (Stoiber-Commission). The OECD does a lot of research in amending and spreading RIA methods. ${ }^{182}$

There is no uniform method of RIA. For decades prognoses, simulations, expert interviews, experimental legislation, report duties of governments, laws with strict time limits (sunset legislation) were used. Following the Dutch example later on in most countries the Standard-Cost-Model $(S C M)$ was applied. The focus of interest of SCM-RIA at the beginning used to be administrative burdens of economy, the citizens, the administration itself, as far as obligations to collect and submit data are concerned (application, focus, statistics, receipts, proofs, references and so on). ${ }^{183}$ This narrow perspective on informations neglected checking and measur-

${ }^{179}$ Law of 14 August 2006 (Fed Gaz. I 1866); Law of 16 March 2011 (Fed.Gaz.I 420). For more details, see H. GRÖHE and S. NAUNDORF, 'Bürokratieabbau und bessere Rechtsetzung, Eckpunkte, Erfahrungen und Perspektiven' (2009) Zeitschrift für Gesetzgebung 367.

${ }^{180}$ U. KARPEN, 'Wachhund' (Frankfurter Allgemeine Zeitung, 11 July 2006).

${ }^{181}$ See now the Report to Congress on the Costs and Benefits of Federal Regulation and Unfounded Mandates on State Local and Tribal Entities (2006).

${ }^{182}$ Cf. OECD, Cutting Red Tape, Why Is Administrative Simplification So Complicated: Looking Beyond 2010 (OECD 2010); 'Regulatory Governance Initiative in South East Europe: The Use of RIA to foster Efficiency and Policy Coherence' (OECD Stability Pact seminar, Sofia, Bulgaria, 23-24 January 2003) <http://www.oecd.org/gov/regulatorypolicy/1842008.pdf> accessed 30 September 2012.

${ }^{183}$ Bertelsmann Stiftung, Handbuch zur Messung von Regulierungskosten (Bertelsmann Stiftung 2009) 8. See in detail the Handbook on Methods: ProgrammBürokratieabbau und Bessere Rechtssetzung (2006), as edited by the Federal government and the Federal Office of Statistics. 
ing costs of other legal obligations, although these outweigh costs of data collection. In Germany and other countries now the focus of RIA shifts to costs of implementation of laws by enterprises, citizens and administrative bodies. ${ }^{184}$ In European Union offices, in Sweden, in the Netherlands and in the United Kingdom nowadays the Net-Administrative-Cost-Model $(N A C M)$ is applied. ${ }^{185}$ The advantage of this model is that RIA of several single aspects of implementing a law are united in one procedure. This leads to better transparency of economic, social and ecological effects of new legislation.

The RIA results generally are reported in the preamble and/or the arguments of a draft. This enables parliament to check and discuss the costside of a draft in detail. ${ }^{186}$

\section{TECHNIQUES OF LEGISLATION}

\section{Law Drafting}

Legistics deals in view of legislation next to 'who', 'why', 'what' also with issues of 'how' to draft norms. This is the question of formal quality, style, structure, language, the use of references, general clauses and so on. Drafting technique, however, does not only have a formal character. It refers to the content of the draft, shapes it and is influenced by it. Form and content are in a dialectic tension. Method, procedure and technique of norm drafting are linked. For systematics, form of regulation, wording, publication and other technicalities the content is influential. Choice of language depends on the addressees, procedure on form and content, namely its importance. ${ }^{187}$ An optimal connection of these elements strengthens effectiveness of the norm and renders a 'good law' as piece of art:

Trop de textes ne permettent pas de distinguer l'intention de l'action, le possible du souhaitable, l'accessoire de l'essentiel, le lici-

${ }^{184}$ Bundeskanzleramt, Leitfaden zur Ermittlung und Darstellung des Erfüllungsaufwands in Regelungsvorhaben der Bundesregierung (2011) 6. As well in the Netherlands (see C. RADAelli and F. de FranCESCO, Regulatory Quality in Europe: Concepts, Measures and Policy Processes (Manchester University Press 2007)), and France (see Conseil Scientifique de l'Évaluation, Petit Guide de l'Évaluation des PolitiquesPubliques (1996).

${ }^{185}$ Commission (2005), 97/5. See also EU Impact Assessment in the Commission, International Guideline on the New Impact Programme Development for the Commission Service; Commission, 'Impact Assessment' (Communication) COM (2002) 276 final; Commission, 'Better Regulation for Growth and Jobs in the European Union' (Communication) COM (2005) 97 final.

${ }^{186}$ Die Bundesregierung, 'Gemeinsame Geschäftsordnung der Bundesministerien’ (Bundesministerium des Innern, 05 November 2011) <http://www.bmi.bund.de/SharedDocs/ Downloads/DE/Veroeffentlichungen/ggo.html?nn=110430> accessed 30 September 2012 at [44.5].

${ }^{187}$ G. MÜLLER, Elemente einer Rechtssetzungslehre (2nd edn., 2006)' 48. 
te de l'illicite. Toute loi mal faite - parce qu'elle nourrit l'incertitude, provoque la désillustion ou facilite la fraude - est une attainte portée à la securité juridique du citoyen. ${ }^{188}$

I am not being entirely frivolous when I remind you that Moses was an excellent draftsman. When he said ,Thou shall not steal', everyone knew what he meant. But we have the Theft Act 1978 with 36 sections, which have given rise to many problems of interpretation, which have had (...) considered many times by the Court of Appeal. ${ }^{189}$

Drafting techniques have developed well in practice. ${ }^{190}$ Clarity, precision, avoidance of contradictions, readability and comprehensibility are constitutional directives. These qualities are vested in rule of law. In the words of the UN:

The 'rule of law' refers to a principle of governance, in which all persons, institutions and entities, public or private, including the state itself, are accountable to laws that are publicly promulgated, equally enforced and independently adjudicated and which are consistent with international human rights, norms and standards. It requires, as well, measures to ensure adherence to the principles of supremacy of law, equality before the law, fairness of application of the law, separation of powers, participation in decision-making, legal certainty, avoidance of arbitrarism and procedural and legal transparency. ${ }^{191}$

This comprehensive definition covers all important points for 'good legislation'. Obeying these rules for linguistically and technically 'good norms' increases trust in legislation and trust is a prerequisite for acceptance and application of law. ${ }^{192}$

${ }^{188}$ C. BeRgeal, Rédiger un TexteNormatif (6th edn., 2008) 141.

${ }^{189}$ Lord Renton, The Evolution of Modern Statute Law and its Future (University College 1995) 8.

${ }^{190}$ H. MÜLLER, Handbuch der Gesetzgebungstechnik (2nd edn., 1968); G.C. THORnTON, Legislative Drafting (3rd edn., Butterworths 1987); C. Bergeal, Rédiger un textenormatif (6th edn., 2008); M. CUTTS, Lucid Law:, The Plain Language Commission (1994); M. CUTTS and E. WAGNER, Clarifying EC-Regulations: The Plain Language Commission (2002); C. STEFANOǓ and H. XANTHAKI (eds.), Drafting Legislation: A Modern Approach (Ashgate 2008) $63 \mathrm{ff}$.

${ }^{191}$ UNGA, 'Report of the Secretary-General on the Rule of Law and Transitional Justice in Conflict and Post-conflict Societies' (2004) U.N. Doc. S/2004/616, no. 6.

${ }^{192}$ U. KARPEN, 'Good Governance Through Transparent Application of the Rule of Law' (2009) 11 European Journal of Law Reform 213; A. Pizzorusso, 'La Méthode Législative en Italie' in C.A. MoRAnd (ed.), LégistiqueFormelle et Matérielle, Formal and Material Legistic (1999) 61-78. For France, see O. JouANJAN, 'Grundlage und Grundzüge Staatlichen Verfassungsrechts: Frankreich' in A. vON Bogdandy et al. (eds.), Handbuch Ius Publicum Europaeum (vol. 1, C. F. MÜLLER 2007) no. 105. Europarat, Access to Legal Norms, Straßburg 2009. 
In reality of legislation these rules, however, are often neglected. This is a standing complaint in all countries. ${ }^{193}$ Unfortunately this is true for European legislation as well. Neither is it transparent nor 'close to the citizens'. Instead, it is often superfluous and irritating. The confusing level of details very often is the effect of a lack of consent of member states. Some agree only then to a regulation, if and when peculiarities of their national legal system are taken into account by special regulations or reservations of that particular European regulation. ${ }^{194}$ Some improvement of transparency is expected by electronic publication, but this seems not to be sufficient.

\section{Structure, Language, References}

Good disposition and structure of a draft, transparent systematics, are the red rope for comprehension of the text and finding the norm which needs to be applied in the case. These qualities demonstrate the unity of the legal order. ${ }^{195}$ Deficits with regard to content and form of the old Swiss Constitution were - according to the arguments of the new draft - the main reasons for drafting the most modern constitutional text of today, the new Swiss Constitution of $1999 .{ }^{196}$ There was consent that the old constitution by virtue of many amendments was a sufficient regulation of most issues; over the years, however, it degenerated into an incomplete, intransparent and incomprehensive piece of patchwork.

All countries aim at strengthening legislative functions of regulation, steering, orientation and limitation by consolidation and codification of laws. However, urgent daily political problems are not favouring good legislation; it is hectic, superfluous and too detailed. ${ }^{197}$ Sometimes complexi-

${ }^{193}$ For Switzerland, see G. MüLLER, Elemente einer Rechtssetzungslehre (2nd edn., 2006) 157 ff.; for the United Kingdom, see J. BATES, 'United Kingdom' in U. KARPEN (ed.), Legislation in European Countries (1996) 452 ff., who writes about 'a rather opaque and elliptical style'; for Germany, see U. KARPEN, I. BREUTZ and A. NÜNKE, Gesetzescheck: Die Gesetzgebung der Großen Koalition in der ersten Hälfte der Legislaturperiode des 16. Deutschen Bundestages (2005-2007) (2007) 166 ff.; for France, see C. BERGEAL, Rédiger un Texte Normatif (6th edn., 2008) $13 \mathrm{ff}$.

${ }^{194}$ G. MÜLLER, Elemente einer Rechtssetzungslehre (2nd edn., 2006) 158, no. 519; see also J. BAtes (2009) 50 Legislação: Cadernos de Ciência de Legislação 291.

195 On France, see C. BergeAL, Rédiger un TexteNormatif (6th edn., 2008) 226, 228; on the UK, see W. Dale, Legislative Drafting: A New Approach (Butterworths 1977) 331 ff.; G.C. ThORnTON, Legislative Drafting (3rd edn., 1987) ch. 7.

196 H.H. Vogel in A. VON BogdAndy et al. (eds.), Handbuch Ius Publicum Europaeum (vol. 1, C. F. MÜLleR 2007) no. 27.

${ }^{197}$ C.A. MORAND in C.A. MorAnd (ed.), Légistique Formelleet Matérielle, Formal and Material Legistic (1999) 23. 
ty of a matter does not allow for comprehensive codification. The German Social Security Legislation has not yet been completed, and a comprehensive codex for ecology could not be drafted: the matter was too diverse and new. ${ }^{198}$ In the United Kingdom there are still reservations versus statutes and codifications, 'so-called «bloody code(s)»'. When in the 19th century drafting a Criminal Code was discussed, one of the most noticeable common law-judges of his time said:

I feel bound to your Lordship that in my opinion the proposed measure, which is to abrogate the common law with regard to criminal offences, and put an end so to all its rules and definitions of offences, substituting statutory enactments is a measure likely to produce no benefit in the administration of criminal justice, but decidedly the reverse. ${ }^{199}$

In the meantime, the Criminal Act of 1854 has been amended several times, last in 2000 and 2003.

«Whatever is well conceived is clearly said. And the words to say it flow with ease.» ${ }^{200}$ The language of norms is an inexhaustible topic. It must be clear and precise: «[I]t is not enough to attain a degree of precision which a person reading in good faith can understand, but it is necessary to attain, if possible, a degree of precision which a person reading in bad faith, cannot misunderstand.» 201

The language must be oriented towards addresses and function of the law. Traffic law, criminal law, contract law must be accessible and understandable to everybody. ${ }^{202}$ Provisions on limits of air pollution, noise, obnoxious materials, protection against ionizing radiation are made for experts. Texts of this kind are supplemented by matrixes, graphs, formulas and plans. Some countries have to legislate in more than one language, e.g. Switzerland, Belgium and Canada. ${ }^{203}$ According to Article 2 of the French Constitution ' $[\mathrm{t}]$ he language of the Republic is French'. The European Union is a multilingustic association of states. The battle on gendercorrect language goes on: 'chairman-chairwoman-chair', 'he-she-one' and

${ }^{198}$ K. VON BEYME, Der Gesetzgeber (1997) 71.

${ }^{199}$ Lord Justice Thomas and R. WRIGHT, 'Lawmaking in England and Wales: Access to Justice' (2009) 50 Legislação: Cadernos de Ciência de Legislação 277, 285 ff.

${ }^{200}$ Nicolas BoILEAu-DÉSPEREAuX (1636-1711), The Art of Poetry (1674), Canto I, I 153, Germaned, Stuttgart (Reclam) 1967.

201 J. STEPhen, Practical Legislation (John Murray 1902) 9, as cited by G.C. Thornton, Legislative Drafting (3rd edn., Butterworths 1987) v.

${ }^{202}$ Even if laws are rarely read. See G. MüLLER, Elemente einer Rechtssetzungslehre (2nd edn., 2006) 182, 185.

${ }^{203}$ G.C. Thornton, Legislative Drafting (3rd edn.,Butterworths 1987) 79. 
so on. Hopefully one can avoid linguistic attacks on 'hu-man' or 'mankind'. ${ }^{204}$

All legislators use drafting techniques. ${ }^{205}$ Among them are legal definitions, references, repetitions. Definitions are ambivalent. They could be lighthouses in the ocean of norms, but as well provide extreme details. The latter is true with European Legislation, not at least due to the fact that twenty-seven national legal systems must be brought to overlap. ${ }^{206}$ References are an instrument of integration of the legal order, and to implement new regulations into the existing body of law. ${ }^{207}$ Other drafting techniques may be found in some legal orders, e.g. formula compromises, legal assumptions.

There are complaints that many regulations suffer from insufficient publicity, accessibility and understandibilitiy. Austrian courts ${ }^{208}$ have criticised that 'the diligence of an archive keeper' is required to find out some provisions and that there are norms which could be found only with 'subtle expert knowledge, extraordinary methodological expertise and some pleasure to solve brainteasers'. Some countries - and the European Union - have started to publish laws in electronic form - Austria, Belgium - others support printed publications with Internet and Computer-techniques. ${ }^{209}$

\section{Special Categories of Laws (Amendments and so on.)}

Manuals for better drafting are devoted to a major extent to special forms of legislation. ${ }^{210}$ Due to the torrent of laws and their hectic sequence $^{211}$ amendments are of particular interest.

${ }^{204}$ W. Voermans, 'Styles of Legislation and Their Effects' in 32(1) Statute Law Review $38,42 \mathrm{ff}$.

${ }^{205}$ J. HeLLNER, Technik der schwedischen Gesetzgebung auf dem Gebiet des Vermögensrechts [1991] Zeitschrift für Gesetzgebung 347.

${ }^{206}$ U. KARPEN, I. BREUTZ and A. NÜNKE, Gesetzescheck: Die Gesetzgebung der Großen Koalition in der ersten Hälfte der Legislaturperiode des 16. Deutschen Bundestages (2005-2007) (2007) 169. See also G.C. Thornton, Legislative Drafting (3rd edn., Butterworths 1987) ch. 5.

${ }^{207}$ C. Bergeal, Rédiger un Texte Normatif (6th edn., 2008) no. 248; G.C. THORnTON, Legislative Drafting (3rd edn., Butterworths 1987) 72.

${ }^{208}$ E. WIEDERIN in A. VON BOGDANDY et al. (eds.), Handbuch Ius Publicum Europaeum (vol. 1, C. F. Müller 2007) no. 174.

${ }^{209}$ Lord Justice ThOMAS and R. WRIGHT, 'Lawmaking in England and Wales: Access to Justice' (2009) 50 Legislação: Cadernos de Ciência de Legislação 277, 281 ff.

${ }^{210}$ H. MÜLLER, Handbuch der Gesetzgebungstechnik (2nd edn., 1968) 22 ff.; G. MÜLLER, Elemente einer Rechtssetzungslehre (2nd edn., 2006) ch. 9; H. SCHNEIDER, Gesetzgebung (3rd edn., 2002) ch. 8; W. ISMAYR (ed.), Gesetzgebung in Westeuropa (VS Verlag für Sozialwissenschaften 2008) 14; C. BERGEAL, Rédiger un Texte Normatif (6th edn., 2008) nos. 63 ff.; G.C. Thornton, Legislative Drafting (3rd edn., Butterworths 1987) 100 ff., 336 ff., and $356 \mathrm{ff}$.

${ }^{211}$ In all countries amendment-laws are much more numerous than 'spring-laws' (laws, which regulate on a matter for the first time). For Germany, see U. KARPEN, I. BREUTZ and 
In the drafting literature the reader will find details on 'legislative packages', time-limited and experimental laws, symbolic and 'show-window'-legislation, authorisation legislation (for delegated legislation), ${ }^{212}$ budget laws, ${ }^{213}$ 'coat laws' and laws which transform international or European law into national law.

A comparative Dutch study proved for the United States, Germany and the Netherlands that laws on measures in individual cases ( $a d$ hoc laws) contradict many constitutional principles which finally are based in rule of law: ${ }^{214}$ general application of a law, equality, trust, proportionality, separation of powers, fair procedure, access to courts and others. Measurement laws and exceptional provisions need to be avoided.

In view of intransparency of huge numbers of laws, in most countries special legislation is used to abolish (outdated) laws or to publish them in a purified form or to consolidate larger areas of law. These techniques to keep the body of law up to date, smooth and transparent have been made easier by applying IaC-technology. ${ }^{215}$

\section{Guidelines and Manuals for Law-Making}

Prior to be initiated in parliament, drafts - as mostly written in the line ministries - are checked, whether they comply with constitution and law. This is done in the central office of government (Prime Minister, President and so on.) or in the Ministry of Justice. ${ }^{216}$ To coordinate legislation, and to assist drafters, most governments have implemented legislative guidelines.

This is true for Belgium, the Netherlands, Germany, France, the United Kingdom, Sweden, Italy, Switzerland, Canada and the European Un-

A. NÜNKE, Gesetzescheck: Die Gesetzgebung der Großen Koalition in der ersten Hälfte der Legislaturperiode des 16. DeutschenBundestages (2005-2007) (2007) $250 \mathrm{ff}$. Referring to amendments, see also C. Bergeal, Rédiger un TexteNormatif (6th edn., 2008) no. 221; G.C. THORNTON, Legislative Drafting (3rd edn., Butterworths 1987) ch. 15.

${ }^{212}$ G.C. ThORnTON, Legislative Drafting (3rd edn.,Butterworths 1987) ch. 16.

${ }^{213}$ For the EU-budget, see I. HÄRTEL, Handbuch Europäische Rechtssetzung (Springer 2006) 403.

${ }^{214}$ A. JASIAK, Constitutional Constraints on Ad Hoc Legislation (2010) 314.

${ }^{215}$ In 2005 acommission made a complete revision of all norms as released till 2004. This program is continued in the frame of 'Better Regulation'. See Commission, 'Smart Regulation in the European Union' (Communication) COM (2010) 543 final.

${ }^{216}$ For distribution of competences in Germany, see Bundesministerium der Justiz, Handbuch der Rechtsförmlichkeit: Empfehlungen des Bundesministeriums der Justiz zur einheitlichen rechtsförmlichen Gestaltung von Gesetzen und Rechtsverordnungen (3rd edn., Bundesanzeiger 2008) $16 \mathrm{ff}$. In Great Britain all statutory instruments (delegated legislation as enacted by Government) are reviewed by (Joint) Committees of both Houses. See J. BATES, 'United Kingdom' in: U. KARPEN (ed.), Legislation in European Countries (1996) 439. 
ion. ${ }^{217}$ Many of these guidelines start - of course - from the same principles and include similar examples of good or bad legislation. Finally, these guidelines are conventions, rules of best practice, which could be addressed as 'loi des lois ${ }^{218}$. ${ }^{219}$ The most voluminous and very colourful collection of drafting guidelines has been written by Rodolfo Pagano. ${ }^{220}$ The best manual currently in use is the Swiss one..$^{221}$

Codified law in common law countries often uses the methodology of judge-made interpretation. The judge adheres to precedents and principles as derived from them. Only carefully - in reasoning from case to case they are developed. Broad, goal-oriented or historical interpretation is rarely dared. This style of applying the law is followed by the legislator: 'le rédacteur doît parler la langue de l'interprêt' ${ }^{222} \mathrm{He}$ drafts statutes finemeshed and very detailed, in order to ensure strict interpretation along the line of the wording; a legitimate reference to common law is almost impossible. By this 'formal method' of drafting - in fact, cases are 'wrapped up' in statutes - the legislator intends to bind the judges as closely as possible to the law. By interpretation guidelines ${ }^{223}$ - in addition - it is exactly prescribed how a law should be understood correctly. This is a

${ }^{217}$ For Belgium and the Netherlands, see W. VoERmans, 'Styles of Legislation and Their Effects' in 32(1) Statute Law Review 38, 43 ff.; for Germany see n. 215. For France, see J.P. DuPRat, 'The Recent Evolutions in French Legislative Practice: A Managerial Conception of Statutes' (2009) 50 Legislação: Cadernos de Ciência de Legislação 261; C. BERGEAL, Rédiger un Texte Normatif (6th edn., 2008) 299, 335. For the United Kingdom, see J. BATES, 'United Kingdom' in U. KARPEN (ed.), Legislation in European Countries (1996) 441. For Sweden, see Das Grönaboken: Riklingrförförfattningskrivning (1998). For Italy, see: Regole e Suggerimentipe la Redazione die TestiNormatisi (1991). For Switzerland, see Swiss Gesetzgebungsleitfaden: Leitfaden für die Ausarbeitung von Erlassen des Bundes (3rd edn., Bundesamt für Justiz 2007). For Canada, see Department of Justice, Federal Legislations Manual (1998); Legislation Deskbook (since 1986). For the EU, see the Gemeinsamen Leitlinien für die Qualität der gemeinschaftsrechtlichen Rechtsvorschriften, ABl. C 73 vom 17.03.1991, p. 1, updated 2008; $c f$. W. Robinson, 'Drafting of EU Acts: A View From the European Commission' in C. Stefanoǔ and H. XANThaKi (eds.) Drafting Legislation, A Modern Approach (Ashgate 2008) $177 \mathrm{ff}$.

${ }^{218}$ C.A. Morand in C.A. MoRAnd (ed.), Légistique Formelle et Matérielle, Formal and Material Legistic (1999) 43.

${ }^{219}$ Comparative observations: Kindermann, Ministerielle Richtlinien der Gesetzestechnik, Verfassungsrechtliche Untersuchung der Regelungen in der Bundesrepublik Deutschland, in Österreich und in der Schweiz, Berlin 1979; U. KARPEN, 'Manual for Law Drafting' in U. KARPEN, Gesetzgebungslehre: Neu Evaluiert / Legistics: Freshly Evaluated (2nd edn., 2008).

${ }^{220}$ R. Pagano, Le Direttive Di Tecnica Legislativa in Europa (vols. 1 and 2, Camera dei Deputati 1997).

${ }^{221}$ Cf. 141.

${ }^{222}$ Loi concernant l'interprétation des lois et des règlement of 1985, c.f. C.A. MORAND (ed.), Légistique Formelle et Matérielle, Formal and Material Legistic (1999) 153, n. 9.

${ }^{223}$ Law on Normative Acts, State Gaz. 27/1979, as amended State Gaz. 65/1995. 
long-term teamwork of legislator and interpreter (the judge) until the law changes.

Some countries go a step further by adopting a law on legislation, like Bulgaria. ${ }^{224}$ There are many good intentions and provisions, indeed, trying to force the legislator to produce good laws.

Unanimity in principles of drafting - whether practiced throughout or not - is developed that far that it might well be possible to mandate a group of experts to collect drafting principles under the umbrella of a model of better legislation. But even if applied the legislator will not always succeed to draft a first class law. There remains a difference between practice and rules, even if the latter are taken from practice

\section{CONCLUSION: SOME TRENDS OF LEGISLATION AND LEGISTICS}

From the comparative law view some four trends of legislation in modern states may be noted.

Legislation and problems as described by legistics are similar but not the same in the constitutional states which this study referred to. To cite Scott Peck again:225 «We should share our similarities and celebrate our differences.» Astonishment over differences is the engine of comparative law. The process of equalisation of legislative procedures, content and form of law will proceed. Europeanisation and globalisation of legislation have gained a common basis by opening of constitutions to the world. European and national constitutional law could be understood as a 'complementary constitution' of a 'constitutional compound' - not yet a confederation or even a federation or, in other words, a constitutional order in which constitutions enrich each other. ${ }^{226}$

However, the importance of parliament will change: it will remain the centre of power in a democratic state. It is under permanent political pressure to guarantee stability and flexibility of the law at the same time. Effectivity of norms is the primordial goal. Quantity of law production versus deregulation, lacking quality, insufficient transparency, increased participation, RIA, governmentalisation on the one hand - regional and federal as well as autonomous legislative competences on the other. ${ }^{227}$

The juridification of legislation will proceed. The judge is part of the legislative process. He finally measures procedure, goals, instruments and

${ }^{224}$ W. VoERMANS, 'Styles of Legislation and Their Effects' in 32(1) Statute Law Review 38.

225 A. WEBER, Europäische Verfassungsvergleichung (Verlag C.H. Beck 2010)428.

${ }^{226}$ W. ISMAYR (ed.), Gesetzgebung in Westeuropa (VS Verlag für Sozialwissenschaften 2008) $58 \mathrm{ff}$.

${ }^{227}$ C.A. MORAND in C.A. MORAND (ed.), Légistique Formelle et Matérielle, Formal and Material Legistic (1999) 43. 
forms of legislation against the constitution. Why should one make a 'law for legislation', when national courts, the European Court of Justice and the European Court of Human Rights influence, shape and direct national as well as European legislature? Again: 'Gulliver enchaîné'!228

Finally, legistics should be aware of its limitations. Legislation should be as good, precise, effective and efficient, as rational as possible, but it never will be mathematics. As John Dickinson said on 13 August 1787 in the Constitutional Assembly of the United States in Philadelphia: «The life of the law has not been logic: it has been experience.» ${ }^{229}$

${ }^{228}$ Century of Lawmaking for a New Nation: U.S. Congressional Documents and Debates 1774-1875 (Farrand's Records, vol. 2, 1991) 278.

${ }^{229}$ O.W. Holmes, The Common Law (Little, Brown, and Co 1881) 1. 



\section{INSTRUCCIONES PARA LOS AUTORES}

1. Temas de interés.-El Anuario Iberoamericano de Justicia Constitucional publica trabajos de investigación originales sobre la Constitución y el sistema de las fuentes, el control de la constitucionalidad y la justicia constitucional, la tutela de los derechos y libertades y el orden axiológico constitucional, así como la interpretación por los Tribunales Constitucionales u órganos equivalentes de las normas de la Constitución, con particularísima preferencia a los países del mundo iberoamericano.

2. Envío de originales.-Los originales, que deberán ser inéditos o en todo caso no haber sido publicados en lengua española, se enviarán en lengua española, portuguesa o inglesa, escritos en microsoft word o en formato compatible, y se harán llegar por correo electrónico, a la dirección public@ @epc.es o, si ello no fuera posible, en soporte electrónico (CD-ROM), a nombre del Secretario de la Revista, a la dirección: CEPC, Plaza de la Marina Española, 9, 28071 MADRID.

3. Formato.-Los originales deberán ir escritos a espacio y medio, en letra Times New Roman, tamaño 12. La extensión total no podrá superar las 30 páginas (10.000 a 12.000 palabras), incluidos notas a pie de página, bibliografía y apéndices en su caso. La primera página incluirá el título, nombre el autor o autores, filiación académica, direcciones de correo ordinario y electrónico y teléfono de contacto. En una segunda página se presentarán dos resúmenes, en español e inglés, de unas 120 palabras cada uno y entre tres y cinco palabras clave (en los dos idiomas).

\section{Normas de edición:}

a) Bibliografía.-Las referencias bibliográficas, que se limitarán a las obras citadas en el trabajo, se ordenarán alfabéticamente por el primer apellido, en mayúsculas, del autor, bajo el título «Bibliografía» al final del original. Ejemplo:

LÓPEZ LÓPEZ, JUAN (2005): «La reforma de la Constitución», Revista de Estudios Políticos, núm. 80, págs. 20-35.

LÓPEZ LÓPEZ, JUAN (2004): Derecho Constitucional, Madrid, CEPC.

Si se citan dos o más obras de un determinado autor publicadas en el mismo año, se distinguirán por medio de una letra. Ejemplo: LÓPEZ LóPEZ (2005a) y LÓPEZ LÓPEZ (2005b).

b) Notas a pie de página.-Todas las notas irán a pie de página, numeradas mediante caracteres arábigos y en formato superíndice. No se incluirán las referencias bibliográficas completas, sino solamente su forma abreviada. Ejemplo: LÓPEZ LÓPEZ (2005): 90.

c) Citas.-Las citas irán entrecomilladas. Si exceden de tres líneas irán separadas del cuerpo principal del texto, sangradas y a espacio sencillo. Cualquier cambio introducido en la cita original deberán indicarse encerrándolo entre corchetes.

5. Proceso de publicación.-El Anuario Iberoamericano de Justicia Constitucional acusará recibo de todos los originales en el plazo de treinta días desde su recepción. El Consejo de Redacción decidirá la publicación de los trabajos sobre la base, en su caso, de informes de evaluadores externos. La publicación podrá quedar condicionada a la introducción de cambios con respecto a la versión original. La decisión sobre la publicación no excederá de un año. Los autores de artículos aceptados para su publicación podrán, en su caso, ser requeridos para la corrección de pruebas de imprenta, que habrán de ser devueltas en el plazo de un mes. No se permitirá la introducción de cambios sustanciales en las pruebas, quedando éstos limitados a la corrección de errores con respecto a la versión aceptada.

6. Copyright.-Es condición para la publicación que el autor o autores ceda(n) a la Revista, en exclusiva, los derechos de reproducción. Si se producen peticiones de terceros para reproducir o traducir artículos o partes de los mismos, la decisión corresponderá al Consejo de Redacción.

7. Advertencia.-Cualquier incumplimiento de las presentes Normas constituirá motivo para el rechazo del original remitido.

\section{COMENTARIOS BIBLIOGRÁFICOS}

El Anuario Iberoamericano de Justicia Constitucional no acepta reseñas o comentarios bibliográficos no solicitados. Agradece, por el contrario, sugerencias sobre libros para su recensión. 


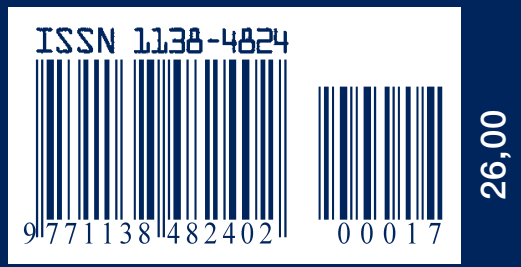

